\author{
Carlos Casale
}

Profesor Facultad de Teología

Pontificia Universidad Católica de Chile

\title{
¿Cómo hacer afirmaciones con pretensiones de universalidad a partir de acontecimientos contingentes? El ejemplo de Cristo en la filosofía
}

\section{PLANTEAMIENTO DEL PROBLEMA}

\section{Acerca de la pregunta que nos convoca}

En este Seminario Interno de Profesores nos enfrentamos a un desafío, el de preguntarnos por la posibilidad y el derecho de llevar a cabo afirmaciones teológicas universales, o si se quiere absolutas, a partir de una revelación particular histórica, de acontecimientos contingentes.

Esta compleja problemática ha venido sobrevolando a la mayoría de las discusiones y disputas que hemos mantenido en los años precedentes en esta misma instancia. Así, y solo por referirnos a los últimos Seminarios, hemos dialogado y discutido sobre la libertad en perspectiva teológica, las mediaciones de la salvación, la credibilidad del cristianismo, la relación entre hermenéutica y teología, la pregunta teológica por la felicidad y la temática de la vida desde la perspectiva de la fe (1). En todas estas ocasiones ha quedado la sensación de la necesidad de una más fina y profunda fundamentación de la problemática subyacente a aquel desafío. Así entonces surgen las siguientes interrogantes: ¿cómo realizar afirmaciones universales -y por ello con pretensiones de verdad- a partir de acontecimientos concretos e históri$\cos$ ? (2), ¿bajo qué condiciones, en un mundo donde el cristianismo es considerado un "subsistema", como nos recordaba hace poco un filósofo luhmanniano (3), está justificado hacer asertos con exigencias de universalidad?

(1) Cf. respectivamente los siguientes números de Teología y Vida que han dado cuenta de estos Seminarios: vol. 40 n. 1-2 (1999); vol. 42 n. 1-2 (2001); vol. 45. n. 2-3 (2004); vol. 46. n. 1-2 (2005); vol. 47 n. 2-3 (2006); vol. 48 n. 1 (2007).

(2) No hay que olvidar que la Modernidad en gran parte ha sido marcada por uno de sus "padres", Lessing, quien afirmaba que las "verdades contingentes de la historia no pueden jamás constituir la prueba de verdades eternas de la razón" (zufällige Geschichtswahrheiten können der Beweis von notwendigen Vernunftwahrheiten nie werden [Über den Beweis des Geistes und der Kraft, en: G. E. Lessing, Werke, vol. 8, München 1976, 12]).

(3) Cf. A. Mascareño, Sociología de la felicidad: lo incomunicable, Teología y Vida 47 (2006), 190208. En una línea análoga, el sociólogo Pedro Morandé nos ha propuesto a los teólogos chilenos 
Lo que aquí está latente y que ha sido expuesto con diferentes variantes en la historia de la teología desde sus inicios es una de las problemáticas claves, sino la más importante, a mi parecer, del cristianismo (4) (si es que lo entendemos a este como esencialmente misional-pastoral), y que se puede sintetizar en la siguiente pregunta: ¿cómo justificar racionalmente, y esto no solo por una acomodación a los dictados de la razón moderna sino por una necesidad interna de la misma fe, que no puede ser "irracional", que el fundador y centro, la "esencia del cristianismo", Jesucristo, pueda ser propuesto y "profetizado" como la verdad interpelante y "adveniente" (Geffré) en cada época y para toda cultura, a todo hombre transido por la necesidad arcaica de una certeza infalible?; es decir, ¿por qué y bajo cuáles premisas un rabbí del siglo primero que gozó de gran prestigio entre sus seguidores y que fundó una iglesia, puede ser "predicado" como en quien se revela la "verdad" del mundo, quien, según el Evangelio de Juan ("... yo soy la verdad"), exige para sí como revelador escatológico del Padre un reconocimiento ortopráxico como "la" verdad? (5). Se trata, en el fondo, de hacerse cargo en la teología actual del desafío misional de Gaudium et spes no 22 (6) y de la declaración de Juan Pablo II en los inicios de su pontificado, al afirmar que Cristo es "la clave para entender con profundidad creciente la realidad que es el hombre. En definitiva no se puede comprender al hombre sin Cristo. O mejor, el hombre no puede entenderse a sí mismo profundamente sin Cristo. No puede comprender quién es él, en qué consiste su verdadera dignidad ni cuál es su vocación y su determinación definitivas. Sin Cristo, todo eso resulta incomprensible para el hombre" (7). Recientemente, en la misma

sugerentes reflexiones; así por ejemplo, en el marco del Centro Manuel Larraín, nos ha repetido la tesis, antes expuesta de Mascareño, y ha agregado, desde la perspectiva de la sociología, que en relación a la "verdad del cristianismo" se da la "paradoja" que la verdad sería el hecho de lo religioso, la religión, y el "caso" único, difícilmente comunicable, el acontecimiento cristológico, v. gr. el cristianismo: ¿no serán estas inteligentes preguntas las que con más urgencia que nunca nos deben convocar a reflexionar en este Seminario en vistas a buscar una forma de pensar la verdad que justamente haga de un caso el "desocultamiento" de la plenitud de la verdad?

(4) Cf. R. Bernhardt, La pretensión de absolutez del cristianismo. Desde la religión hasta la teología pluralista de la religión, Bilbao 2000. Muy iluminador y quizá una de las mejores presentaciones sobre muchos de los tópicos que nos convocan en este Seminario es la obra de M. Knapp, Verantwortetes Christsein heute. Theologie zwischen Metaphysik und Postmoderne, Friburgo 2006, para este autor es especialmente relevante que las relaciones entre teología y pensamiento moderno no se mantengan al precio que este último tenga que renunciar a sus propias estructuras frente a los contenidos teológicos, sino que sea capaz de descubrir en ellos una posibilidad de "plenitud" y "fundamentación última" de la existencia.

(5) Cf. P. Hünermann, Cristología, Barcelona 1997, 13-72; H. Hoping, Einführung in die Christologie, Darmstadt 2004, 16-18; W. Kasper, Einführung, en: id., (ed.), Absolutheit des Christentums, Freiburg 1977, 7-11; C. Geffré, El cristianismo ante el riesgo de la interpretación. Ensayos de hermenéutica teológica, Madrid 1984, 86ss.265ss.

(6) "En realidad, el misterio del hombre solo se esclarece en el misterio del Verbo encarnado... Cristo, el Nuevo Adán, en la misma revelación del misterio del Padre y de su amor, manifiesta plenamente (plene manifestat) el hombre al propio hombre y le descubre (patefacit) la sublimidad de su vocación... Así pues no es nada extraño que las verdades (veritates) ya indicadas encuentren en Él su fuente y alcancen su culminación (suum invenire fontem atque attingere fastigium) [...] Por Cristo y en Cristo se ilumina el enigma del dolor y la muerte, que fuera del evangelio nos envuelve en oscuridad absoluta". Cf. el excelente comentario a Gaudium et spes de H. J. Sander, en: P. Hünermann-B. J. Hilberath (eds.), Herders Theologischer Komentar zum Zweiten Vatikanischen Konzil, vol. 4, Friburgo 2005, 581-886, aquí sobre todo 739-743.

(7) Homilía en la Plaza de la Victoria, Varsovia, el 2 de junio de 1979, en: Osservatore Romano (ed. en español), 10 de junio 1979, 6 . 
línea, la Conferencia Episcopal de Chile ha señalado a Jesucristo como la "referencia fundamental" en relación a la cual se descubre la verdad del hombre, la sociedad y la creación (8).

Lo recién señalado nos retrotrae a una convicción muy importante, y que Pannenberg (9) ha analizado profundamente: la filosofía ha sido, desde sus inicios, una aliada fundamental para la misión de la Iglesia, para su envío evangélico de predicar y anunciar a Cristo como la revelación definitiva de Dios y con ello, consiguientemente, del sentido y fin de toda la creación. Esta unión entre teología y filosofía no está por cierto exenta de límites y de detentar un carácter provisorio; pero es necesaria para afirmar en la actualidad, bajo los requerimientos ilustrados $-\mathrm{O}$ si se quiere postilustrados- frente a los cuales hay que "dar razón de nuestra esperanza", Jesucristo, que aquel judío que vivió durante la época de Herodes es la "estructura" (Framework, como dice Gunton) de la creación, pues la filosofía tiene como tarea hablar del "todo" (10), tener alcance universal en sus reflexiones. De ahí pues la hipótesis de que una de las formas de "empezar" a encontrar pistas para iluminar la problemática de cómo hacer en teología afirmaciones sobre algo particular con pretensión universal, pasa ineludiblemente por dotar al lenguaje teológico de una modulación, de una mediación filosófica (11). En especial nos detendremos en un tipo de pensamiento filosófico que no ve necesariamente como disyuntivos lo particular concreto y lo universal, que no tiene por contradictorio o antagónico lo contingente y lo necesario (12).

Para profundizar en la necesaria mediación filosófica de la teología para poder hablar de un "universal concreto" (Balthasar), en la siguiente presentación reflexionaremos -o mejor dicho, nos pondremos a la escucha- sobre algunos filósofos fundamentales que conservan una importancia perenne a la hora de interrogarse por las cuestiones fundamentales de la existencia, tanto desde la perspectiva de la ética como de la ontología, y que al interior de sus sistemas, de su lógica (Sachlogik) y estructuras formales de pensamiento se han dejado cuestionar por Cristo (su doctrina, su persona, o ambos aspectos). Esto último es muy significativo para nuestro planteo, pues cuando un pensador se adentra profundamente en las preguntas a las que convoca el acercamiento al ser, la historia, la libertad, Dios, etc., y en este contexto aparece la figura interpelante de Jesucristo (así, por ejemplo, según Kasper, la cruz se convierte en el "punto crucial" de la filosofía de Schelling (13)), esto

(8) En camino al Bicentenario, Documento de trabajo, Santiago 2004, 9ss.

(9) Cf. Una historia de la filosofía desde la historia de Dios, Salamanca 2001, sobre todo $11 \mathrm{ss} .23 \mathrm{ss} .45 \mathrm{ss} .123 \mathrm{ss} .403 \mathrm{ss}$.

(10) Según Hegel "Lo verdadero es el todo" (Das Wahre ist Das Ganze), tal como lo dice en Phänomenologie des Geistes, Hamburg ${ }^{6} 1952,21$; cf. J. Werbick, Den Glauben verantworten. Eine Fundamentaltheologie, Freiburg 22000, en especial 165-171. Muy inspirador para nuestras reflexiones resulta el estudio de W. Pannenberg, ¿Qué es la verdad? en: id., Cuestiones fundamentales de teología sistemática, Salamanca 1976, 53-76, que desarrolla la tesis que "la pregunta sobre la verdad de la fe cristiana no puede responderse con la mera aserción de que la verdad sea Jesucristo, sino que únicamente cabrá responderla por referencia al conjunto de la realidad que experimentamos. Solo así se echará de ver la unidad de la verdad, que le es esencial" (53-54).

(11) Cf. el importante estudio de K. Lehmann, Absolutheit des Christentums als philosophisches und theologisches Problem, en: W. Kasper (ed.), Absolutheit des Christentums, 13-38.

(12) Cf. las lúcidas reflexiones de C. Geffré, El cristianismo ante el riesgo, sobre todo $160 \mathrm{ss}$.

(13) Cf. Crisis y nuevo planteamiento de la cristología en Schelling, en: AAVV, Teología de la cruz, Salamanca 1979, 210. 
es un indicio, creemos, de tomarse muy en serio la unión que debe haber entre las interrogantes siempre más hondas del hombre y la pregunta por aquella figura. Como penetrantemente señala Peter Hünermann: “¿qué es de una cristología que se manifiesta como un componente esencial (essentielles Moment) de la comprensión filosófica del ser humano y de su puesto en la realidad" (14).

Analizaremos sumariamente, en un primer paso (I), cómo al interior de la "estructura formal" de los planteos de los autores elegidos Cristo aparece interpelando el pensar, un particular con alcance universal, pues de alguna manera toca las dimensiones más profundas del ser. O dicho de otro modo: ¿cómo y por qué Cristo se convierte en un "llamado" fundamental para el filosofar? Luego, en un segundo paso (II), nos haremos cargo, inspirándonos en lo planteado por estos pensadores, en un ejercicio de "reconsideración ontológica", de un tipo de intelección de lo que es verdad que permita hoy en día afirmar al centro del cristianismo (el particular concreto Cristo) como "profecía" de un mundo mejor, más pleno, de una vida más "lograda" (lo universal), sin lo cual esta se hace una carga muy pesada (15).

\section{Algunas aclaraciones previas sobre la temática de Cristo como objeto del filosofar}

Ya que nos proponemos "escuchar" (o como dice nuestro colega J. Noemi a propósito de la cristología en Schelling “... se trata de aproximarse a un pensamiento, de tratar de captarlo, es preciso, en un primer momento, oír, dejarse interpelar y posponer la propia crítica... para evitar esa actitud defensiva y timorata que pueda generar el enfrentarse a un pensamiento de dimensiones tan amplias y profundas, actitud que torna imposible una real recepción e inteligencia" (16)) de qué manera un personaje histórico concreto se ha transformado en un requerimiento universal para importantes filósofos y aprender de ahí la necesidad mediadora -aunque provisoria- del lenguaje filosófico para la teología, cuando esta debe cumplir con su deber misional de hacer aparecer al "centro de su fe" con pretensiones de verdad en cada época y circunstancia, es preciso aclarar, en primer término, bajo qué punto de vista se puede convertir a Cristo en objeto de consideración filosófica. Las dificultades con que, por de pronto, nos encontramos son varias. En primer lugar, Cristo es una persona histórica, mientras que la filosofía se ocupa de asuntos que tienen un alcance general, no circunscrito a este o aquel individuo y aplicable a diferentes cosas o personas en la medida en que tienen algo en común entre sí (por ejemplo

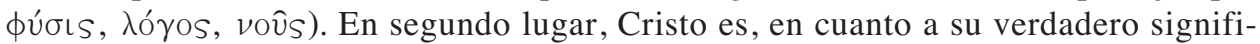
cado, objeto de creencia y, como tal, ajeno a la evidencia racional. Independiente-

(14) Cristología, 377. Hoy en día Franz von Kutschera ha señalado con un vigor digno de atención, desde la filosofía, la importancia de la cristología frente a las "grandes preguntas" del hombre actual, en un tono muy similar a lo que el Concilio Vaticano II plantea como las interrogantes claves del hombre (cf. Die großen Fragen. Philosophisch-theologische Gedanken, Berlin 2000).

(15) Especialmente inspirador fue para nuestro trabajo el pequeño libro de K.-H. Menke, Die Einzigkeit Jesu Christi im Horizont der Sinnfrage, Freiburg 1995.

(16) Jesucristo en la filosofía tardía de F. W. J. Schelling. Una primera aproximación, en: M. Barrios et al. (ed.), Homenaje al profesor Dr. Julio Jiménez Berguecio, S. J., Anales de la Facultad de Teología 33 (1982), 133. 
mente de en qué medida se pueda determinar con métodos historiográficos la existencia de Jesús de Nazaret y, por consiguiente, considerar su vida y su obra como contenido "científico", es decir, intersubjetivamente comunicable. Lo cierto es que su significado ha excedido y sigue excediendo, de forma esencial, este ámbito. ¿Puede acaso la historia pretender decir algo sobre una cuestión que parece sustraerse por completo a su competencia? Esta segunda dificultad se agranda si la ponemos en relación con una tercera, consistente en que la actitud normal, cuando se habla de Cristo, sigue estando determinada, en gran parte, por el convencimiento de que la legitimación para ello proviene de una luz diferente de la habitual, de una luz sobrenatural, de la fe en definitiva, que no se opone a la razón, pero es diferente de ella. La razón, para poder hablar con sentido sobre los contenidos de la fe $-\mathrm{y}$ muy especialmente sobre Cristo, que es su contenido fundamental-, debe estar "iluminada" por la fe. Eso supone que los no creyentes pueden ser considerados como incompetentes para hablar de dichos contenidos y que los mismos creyentes, en cuanto que no son habilitados expresamente para ello, prefieren por lo general dejar el tema exclusivamente en manos de los teólogos. En cuarto lugar, y como consecuencia de lo anterior, sobrevuela también a esta cuestión un prejuicio compartido por muchos, aunque los resultados pueden ser directamente opuestos. Tal prejuicio consiste en que la razón pura y simple, que no parte de considerar a Cristo como objeto de fe y, por tanto, como digno de adoración, lleva inevitablemente a verle de una forma muy diferente de la que es propia de aquel que está impregnado por la fe. La conclusión es que la razón sin más "destruye" a ese Cristo de la fe, lo cual lleva o bien a no querer hablar de él en términos meramente racionales, por cuanto esto supone una profanación injustificada, o bien a intentarlo con vivo interés, con la pretensión, entre otras, de llevar a cabo una tarea digna de elogio, puesto que supone trabajar a favor de la razón y, por lo mismo, en contra de una forma más de superstición.

Así, la cuestión que aquí nos planteamos es si Cristo representa de hecho una interpelación tal para el pensamiento filosófico que a partir de la misma, ya no puede, como tal, mantenerse indiferente ante el fenómeno de Jesús de Nazaret y su significado histórico. Dicho más concretamente, la cuestión no es si Cristo y lo que implica es un tema al que puede referirse la filosofía. Esto no es problema alguno. Lo menos que cabe decir es que sobre él se puede reflexionar filosóficamente en razón de la extraordinaria influencia que ha ejercido en la historia, análogamente a como sobre Napoleón se ha reflexionado también filosóficamente y se ha llegado a formular una especie de nueva categoría para interpretar el proceso histórico, cual es la categoría, acuñada por Hegel, de los "grandes individuos de la historia universal". La cuestión que aquí se plantea es si Cristo representa una interpelación esencial para la filosofía, de forma que, como consecuencia, ya no va a ser posible hacer filosofía sin esa referencia a Cristo y su doctrina. Es la tesis que aquí compartimos, con referencia a nuestro pensamiento occidental. Ello no quiere decir que la referencia sea explícita, ni siquiera que haya entrado a formar parte en todos los casos de la conciencia que la filosofía tiene de sí misma. Tampoco significa que esa referencia, cuando se da, sea siempre positiva, pero sí que allí donde se manifiesta negativamente se revela como en mayor o menor medida dependiendo de aquello mismo que niega, tal como ocurre con algunas fases del pensamiento de Nietzsche y Feuerbach. 
¿En nombre de qué filosofía se legitima la afirmación que aquí defendemos? En nombre, sin duda, de la que se ha ido formando históricamente, sobre todo de aquella que, después de emanciparse del pensamiento medieval, en lo que tiene de teológico, reflexionó filosóficamente sobre el cristianismo y sobre Cristo. Los filósofos que procedieron así y que, no por casualidad, son los más importantes de la filosofía moderna, son casi todos cristianos, pero quisieron simplemente saber lo que para la filosofía y para la razón representaban Cristo y el cristianismo. Por otra parte, en cuanto que consideraron que esas magnitudes se habían convertido en esenciales para la filosofía, reflexionaron sobre ellas desde lo que representaba la incorporación de los mismos, aunque no siempre fueran de ello conscientes. Es este un círculo hermenéutico, cuyo sentido y alcance merecería la pena investigar a fondo.

En estas reflexiones haremos mención de algunos filósofos cuyo punto de vista nos parece muy relevante: Kant, Fichte, Schelling y Hegel (17). Estas indicaciones históricas, forzosamente breves, tienen como finalidad poner de relieve que Cristo ha representado, como decíamos, una interpelación esencial para el pensamiento filosófico o dicho de otra manera, se ha producido el fenómeno que un saber universal le ha dado un lugar capital a un personaje histórico no a través del género de "vida ejemplar", sino como "clave" para que se produzca el mismo filosofar de cara a la conformación de la cultura moderna (búsqueda de autonomía, libertad, ética fundamental, etc.)

\section{CRISTO COMO INTERPELACIÓN AL FILOSOFAR}

\section{Cristo en perspectiva ética: la interpelación de Cristo a la filosofía como ideal moral en el planteo de Kant (18)}

Las reflexiones de Kant se mueven en la línea de un ideal moral a realizar progresivamente en la historia por la comunidad humana El verdadero objeto de los designios divinos -en una idea con clara influencia de Lessing-, el fin de la creación no puede ser otro que "la humanidad (esencia racional del mundo en general) en su completa perfección moral" (19). Al hilo de textos de San Juan interpreta Kant dicha idea suprema de moralidad como idéntica con "el hijo unigénito" (eingeborner Sohn) de Dios, con la palabra, "por la que son todas las cosas y sin la cual no existe

(17) Además de los análisis que realiza de los filósofos que trataremos, ver el trabajo exhaustivo de cf. X. Tilliette, Le Christ des philosophes. Du Maître de ságesse au divin Témoin, Paris 1993; ver también F. Courth, Christhologie. Von der Reformation bis ins 19. Jahrhundert, Freiburg 2000; S. Zucal (ed.), Cristo nella filosofia contemporanea, vol. I, De Kant a Nietzsche, Milan 2000; id., Cristo nella filosofia contemporanea, vol. II, Il novecento, Milan 2002.

(18) Para un primer acercamiento cf. X. Tilliette, El Cristo de la filosofía, 96-104.175-179.202212.250-255; id., Le Christ des philosophes, 75ss; P. Hünermann, Cristología, 366-379; G. B. Sala, Die Lehre von Jesus Christus in Kants Religionsschrift, en: F. Ricken-F. Marty (eds.), Kant über Religion, Stuttgart 1992, 143-155.

(19) I. Kant, Die Religion innerhalb der Grenzen der blossen Vernunft, en: Werke, vol. VII (ed. W. Weischedel), Darmstadt 1968, 712 (versión española: La religión dentro de los límites de la mera razón, Madrid 2001). 
nada de lo que ha sido hecho" (das Wort [das Werde;], durch welches alle andren Dinge sind, und ohne das nichts existirt), entendiendo estas afirmaciones estrictamente bajo el punto de vista de la finalidad o del sentido, no de la causalidad eficiente, pues todo ha sido hecho "en razón de la esencia racional en el mundo" (20). Ahora bien, es "deber humano general que nos elevemos a este ideal de la perfección moral (Ideal der moralischen Vollkommenheit), es decir, al arquetipo (Urbilde) de la actitud moral en toda su pureza" (21). La idea de la moralidad perfecta está presente a la razón y le debe dar a esta la fuerza necesaria para su imitación.

En esta autonomía de la razón insiste Kant en este contexto. Pero por otra parte no es menos cierto que el hombre de por sí es malo y no puede sin más elevarse al ideal de la perfección moral. Este es el punto de partida básico para poder comprender el sentido de la religión (22). Por esto, en lugar de afirmar que el hombre se eleva "al ideal de la santidad", "se puede decir mejor que aquel arquetipo ha descendido del cielo a nosotros, que ha asumido la naturaleza humana... Esta unión con nosotros puede verse como un estado de humillación del Hijo de Dios, si a aquel hombre, poseedor de sentimientos divinos, nos lo representamos como modelo para nosotros, de forma que, siendo santo y no estando, como tal, obligado a soportar sufrimientos, asume estos sin embargo en grado sumo, para promover lo mejor para el mundo" (23). Para que la idea de moralidad perfecta sea eficaz en nosotros, debemos concebirla, pues, como encarnada en un hombre concreto, dispuesto no solo a cumplir el deber en su integridad y a difundir así simultáneamente el bien con la mayor amplitud, sino también a soportar todos los sufrimientos, incluso la "muerte más deshonrosa" (schmählichsten Tode), por el bien de la humanidad y, muy concretamente, por el de sus propios enemigos. "Pues el hombre solo puede hacerse una idea del grado y de la intensidad de una fuerza como es la actitud moral, si se la representa en lucha con obstáculos a los que logra superar, pese a las más graves impugnaciones" (24).

Podemos, pues, resumir la posición de Kant de la forma siguiente: la idea de una moralidad perfecta, única capaz de conferir sentido no solo a la existencia humana, sino a la creación en su conjunto, emana de la esencia misma de Dios, es así increada y eterna, expresión de Dios mismo o, en términos de San Juan, "el hijo unigénito de Dios". Si bien de suyo esta idea es inmanente a la razón, no es un producto de la actividad racional. Nos es presente porque gratuitamente se nos ha hecho presente y ha puesto su tienda entre nosotros. El hombre además, al ser malo por naturaleza, no puede elevarse al ideal de la santidad. Es este el que "desciende" y asume la misma naturaleza humana en la persona concreta de Jesús de Nazaret, quien representa por ello la concreción del ideal de la perfección moral. El sentido de esta encarnación del Verbo de Dios es realizar el ideal moral aún en medio de los mayores obstáculos, sin rehusar incluso la muerte más ignominiosa, y servir así,

(20) Ibíd., 713.

(21) Ibíd.

(22) Cf. Ibíd, 665ss

(23) Ibíd., 718.

(24) Ibíd., 714. 
"mediante la doctrina, la conducta y el sufrimiento", como ejemplo de una humanidad grata a Dios (25).

Cabe decir que Kant combina las tres grandes dimensiones teológicas en torno al significado de Cristo: la trinitaria, por cuanto el ideal de moralidad se concibe como idéntico al "hijo unigénito de Dios" desde toda la eternidad; la dimensión hipostática, en el sentido de que dicho ideal de humanidad nos lo representamos como encarnado en un hombre concreto; y la dimensión soteriológica, al menos en cuanto que Jesús de Nazaret mediante su ejemplo (la Vorbildfunktion de la que habla Courth (26)) nos hace ver que la realización del ideal moral es posible y nos invita a seguir sus pasos (Beispiel der Nachfolge für jedermann).

Parece, pues, que Kant resume puntos centrales de la cristología en lo que tiene además de común a ambas confesiones. Y parece también que, pese a la brevedad con que trata el asunto, la concepción cristológica sirve en buena medida de soporte a la elaboración de la más grave e importante de las cuestiones -el ideal de la perfección moral representa nada menos que el sentido de la realidad como tal, no solo del hombre-. Pero es necesario hacer otras matizaciones. Aparte de la reducción de la religión a la moral, esta mantiene según Kant su carácter estrictamente autónomo. La vida y la doctrina de Cristo tienen así un alcance secundario, sirven como concreción o ejemplificación de contenidos y postulados, que tienen su legitimidad en sí mismos. "En su aspecto práctico esta idea (de la moralidad perfecta o del principio bueno [guten Prinzips]) tiene su realidad completamente en sí misma, pues se da en nuestra razón moralmente legisladora. Debemos actuar de conformidad con ella y tenemos por ello que poder hacerlo" (27).

La personificación o encarnación de esa idea en el hombre que fue Jesús de Nazaret tiene sentido, en último término, como representación, que ayuda a concebir y realizar dicha idea, dadas las imperfecciones y dificultades inherentes a la naturaleza humana. Otra cuestión es si la moral kantiana es concebible al margen del horizonte del cristianismo, o dicho de otra forma, si respecto de la moral kantiana el cristianismo no es un presupuesto que Kant mismo no estaba en situación de clarificar. Por otra parte, Kant se expresa a veces en un tono que abre perspectivas más hondas para el significado del cristianismo, aunque no las llegara a concretar. En el evangelio ve Kant el "hilo conductor de la verdadera sabiduría. Y no solo coincide con él una razón que lleva a cabo su especulación, sino que la razón recibe de aquel una nueva luz por lo que se refiere a lo que continúa siendo oscuro y respecto de lo cual necesita ser adoctrinada, aun después de haber explorado todo su campo" (28). Dicho de otra forma, nada de lo que logra la razón se opone al contenido y al sentido del evangelio; todo cuanto la razón consigue de positivo en el ejercicio de su actividad especulativa coincide, está de acuerdo con el evangelio; y por último, este continúa iluminando a aquella en puntos difíciles y oscuros. Cabría decir que el evangelio es el texto fundamental al que la interpretación racional se atiene riguro-

(25) Ibíd., 716.

(26) Cf. Christologie, 52.

(27) Die Religion innerhalb, 714.

(28) Así en carta a Jung-Stilling en 1789, en: R. Eisler-Kuhn (ed.), Kant-Lexikon, Hildesheim 1964, 78. 
samente, tanto negativa como positivamente, en todas las cuestiones de índole práctico-moral, que son por supuesto las más decisivas.

\section{Fichte: asunción de la perspectiva ética e histórica de Cristo en un horizonte metafísico (29)}

Las aportaciones de Kant podrían considerarse como elaboradas prioritariamente bajo el punto de vista ético (30). Con Fichte nos encontramos ante una dimensión y un horizonte nuevos. Su concepción sobre Cristo, fundamentalmente metafísica, asume de lleno tanto la dimensión ética como la histórica. Nos limitamos, para ilustrar esto, a una referencia breve de la sexta lección de su obra La exhortación de la vida bienaventurada (31).

De entrada, Fichte proclama con cierta solemnidad la coincidencia (Übereinstimmung) de su doctrina con el cristianismo, tal como este se expresa en conceptos e imágenes a través del evangelio de San Juan. Fichte se apresta a precisar que la verdad de su filosofía no se demuestra por la comprobación de tal coincidencia, sino por su evidencia interna, por su consistencia estrictamente racional. Lo que ocurre es que el cristianismo coincide con la razón en cuanto que es "expresión pura y perfecta de la razón" (32) y, como tal, ha de comprenderse a sí mismo.

A primera vista estamos ante un intento de racionalizar el cristianismo, de interpretar su significado en función de esquemas preconcebidos, legitimados únicamente desde un punto de vista inmanente a la razón. Pero la actitud de Fichte no es tan simple. De una parte afirma que, "con completa independencia del cristianismo, el filósofo encuentra las mismas verdades" (33), que encuentra, supuesta ya la existencia histórica del cristianismo. Este es el aspecto bajo el que ha de salvaguardarse la autonomía de la razón. Pero no es menos cierto para Fichte "que nosotros, con toda nuestra época y con todas nuestras investigaciones filosóficas, nos hallamos situados sobre el solar del cristianismo y que hemos partido de él; que este cristianismo ha penetrado de las más variadas formas en nuestra formación y que todos nosotros no seríamos nada de lo que somos si no nos hubiera precedido en el tiempo este poderoso principio (mächtige Princip)" (34).

Fichte proclama la autonomía de la razón y su independencia de cualquier otro principio, incluso del cristianismo. Pero la razón es a su vez histórica, lo que quiere decir en concreto que se ha constituido dentro del horizonte y de los presupuestos del cristianismo. En consecuencia, a la vez que por su autonomía no puede sino atenerse a sus propios principios, el desarrollo de los mismos la ha de llevar por otra

(29) Cf. X. Tilliette, El Cristo de la filosofía, 85ss, 142ss; Le Christ des philosophes, 83ss; E. Brito, La jésuologie de Fichte, Revue Théologique de Louvain 33 (2002), 497-520; J.-Ch. Goddard, La signification christologique de la philosophie selon Fichte, Philosophie 38 (1993), 14-29.

(30) Cf. F. Courth, Christologie, 48-53.

(31) J. G. Fichte, Anweisung zum seligen Leben, Werke, vol. V (ed. I. H. Fichte), Berlin 1971, 475-491 (versión española: La exhortación de la vida bienaventurada, Madrid 1995). Un análisis detallado de esta Lección la ofrece Brito en La jésuologie, 500ss.

(32) Anweisung, 476.

(33) Ibíd., 484.

(34) Ibíd. 
parte al reencuentro con las verdades básicas del cristianismo, únicamente en las cuales podrá salvaguardar su propia identidad. Podría pensarse que nos encontramos ante una reciprocidad circular entre el fides quaerens intellectum y el intellectus quaerens fidem. ¿No estaremos entonces ante uno de tantos residuos históricos, inoperantes por lo demás? Para decidir este punto conviene aclarar brevemente cuál es el contenido del cristianismo.

Fichte lo ve resumido en el Prólogo del Evangelio de San Juan, que representa el "extracto y el punto de vista universal de todos los sermones de Jesús" (35). Nos encontramos aquí con una síntesis de la cristología, semejante en su estructura a la que hemos visto en Kant, pero diferente en su significado, en cuanto que las dimensiones trinitaria, hipostática y soteriológica son interpretadas primariamente bajo un punto de vista metafísico. En primer lugar, Cristo como el primogénito y unigénito de Dios, es la palabra eterna. Ello significa que el mundo y las cosas todas tienen su consistencia en el concepto; son así la "autolocución” (als Gottes Sich-Aussprechen seiner Selbst) de Dios mismo (36). En segundo lugar, esta palabra eterna de Dios se ha expresado, sin mezcla ni imitación alguna, en Jesús de Nazaret, "en un ser existente, sensible y humano en lo personal". Tal proposición, precisa Fichte, no es metafísica, sino histórica. Desde el punto de vista metafísico todo hombre es capaz de captar vitalmente su unidad con Dios y de consagrar de hecho "toda su vida individual a la vida divina". Pero esto se refiere a la posibilidad. Otra cosa es "el medio del devenir real" (37), y en este sentido "el punto de vista exclusivamente peculiar del cristianismo y válido únicamente para sus discípulos" es que Jesús de Nazaret es "por sí mismo... la expresión sensible perfecta de la palabra eterna (die vollkommene sinnliche Darstellung des ewiges Wortes), como no lo fue nadie antes que él" (38). En tercer lugar, cuantos se encuentran dentro del horizonte histórico del cristianismo solo pueden salvarse mediante Jesús de Nazaret y mediante su incorporación a él (39).

Este esquema es muy conocido y enlaza con la más genuina tradición teológica. Pero conviene preguntarse por la motivación de fondo que mueve a Fichte a afirmar la coincidencia plena del cristianismo con su concepción filosófica. Tal motivación no es otra que el reconocimiento de que Jesús de Nazaret fue el primero en tomar conciencia de "la unidad absoluta del ser humano con el ser divino". Como bien dice Brito: "Jesús en efecto ha sido el primero, por decirlo existencialmente, en tener la conciencia de la absoluta identidad de la humanidad y Dios" (40). Es "el conocimiento más profundo (die tiefste Erkenntniss) que el hombre puede alcanzar" (41). Por este "milagro excepcional" es preciso reconocer a Jesús de Nazaret como "el Hijo consustancial y primogénito de Dios" (42). Si bien, metafísicamente ha-

(35) Ibíd., 478.

(36) Ibíd., 481.

(37) Ibíd., 482.

(38) Ibíd., 482-483.

(39) Cf. Ibíd., 487.

(40) La jésuologie, 504.

(41) Anweisung, 483.

(42) Ibíd., 484. 
blando, lo decisivo es unirse realmente con Dios, siendo indiferente por qué camino se llega a esta meta, de hecho, históricamente Cristo no solo fue el primero en señalar el camino, sino que es el camino y la verdad, y por ello es preciso, para lograr dicha unificación, llegar a ser "él mismo y transformarse (werden), sin limitaciones ni reservas (ohne Abbruch oder Rückhalt), en su persona" (43).

Uno se sorprende de que un pensador de la talla de Fichte afirme con tal decisión y radicalidad que la culminación de su filosofía no es otra que la cristología. Habría que analizar varias cuestiones para ver el alcance exacto de tal actitud. En la medida en que la filosofía de Fichte se distancia de las concepciones medievales, es lógico suponer que, pese a todas las semejanzas, la concepción de la propia cristología ha debido modificarse en la misma proporción (44). Más concretamente, bajo tesis que en apariencia asumen sin reservas posiciones de la teología tradicional - unión de hombre y Dios, realización plena de esa unidad en Cristo, necesidad de incorporarse a la persona de Cristo, etc.- están en juego todas las implicaciones del subjetivismo trascendental, que difícilmente deja espacio alguno para el reconocimiento de la personalidad de Dios y de su trascendencia (muy significativa a este respecto es su decidida crítica de la idea de creación), así como para una relación personal del hombre con Dios (45). Y sin embargo, esto no debilita en nada el afán de Fichte por hallar la identidad del propio sistema en una concepción cristológica del mundo y de la vida.

\section{Schelling. De la problemática "doctrinal” sobre Cristo a la "persona de Cristo" como clave interpretativa al problema filosófico fundamental: la libertad (46)}

Para una dilucidación histórica del problema de una filosofía cristológica sería de especial importancia el estudio detallado de los planteamientos de Schelling, que dedica tantos esfuerzos a reflexionar sobre la religión convencido de que esta era la clave para resolver los problemas de la época, que según él "ha llegado a ser completamente teológica”. Aquí nos limitamos a indicar algunos aspectos.

Como punto de referencia cabe indicar que, si en los autores hasta ahora mencionados (Kant y Fichte) la cristología se puede reducir en mayor o menor medida a un problema doctrinal, Schelling afirma ya abiertamente, sobre todo en el último

(43) Ibíd., 488.

(44) Cf. P. Hünermann, Cristología, 241-413; E. Brito, J. G. Fichte et la transformation du christianisme, Lovaina 2004.

(45) También hay que tomar en serio la advertencia de Brito, siempre atento a la "jesuología" de este autor, que "contrariamente a lo que Fichte insinúa, la dignidad incomparable de Jesús no reside solamente en su importancia histórica como mediador de una nueva comprensión de Dios, sino sobre todo en la calidad ontológica y espiritual de la única encarnación del Hijo preexistente" ( $L a$ jésuologie, 512); y más adelante agrega: "Desde un punto de vista teológico, es claro que la gracia de la encarnación no se haya tomada en cuenta" (518).

(46) Para una primera panorámica cf. W. Kasper, Das Absolute in der Geschichte. Philosophie und Theologie der Geschichte in der Spätphilosophie Schellings, Mainz 1965, sobre todo 287-411; W. Kasper, Krise und Neuanfang der Christologie im Denken Schellings, Evangelische Theologie 33 (1973), 366-384; Ch. Danz, Die philosophische Christologie F. W. J. Schellings, Stuttgart-Bad Cannstatt, 1996. 
período de su vida (47), que lo "verdaderamente medular" (der eigentliche Inhalt) no es tanto la doctrina cuanto la persona de Cristo. Con ello no se limita, al igual que Kant y Fichte, a asumir de la tradición teológica el esquema de la humanización del Verbo para acoplarlo a una determinada concepción filosófica. Más bien, Schelling se encara de lleno con el problema de una reinterpretación a fondo de la doctrina teológica sobre la Trinidad y la Encarnación (48). El hilo conductor de todas sus reflexiones está en el concepto de libertad, que él quiere salvaguardar tanto para Dios como para el hombre. Simplificando, podría decirse que el concepto de Dios tiene sentido en la medida en que potencia la libertad humana (el término Potenz, con un significado activo, es central en la obra de Schelling (49)). Simultáneamente, la libertad humana solo se puede fundamentar de una forma convincente y radical si se la ve sustentada en Dios mismo como ser pura y originariamente libre (50). Y todo ello con la intención, por una parte, de hacer plausible la doctrina teológica sobre la Trinidad y sobre la Encarnación y, sobre todo, de enmarcar el problema en el propio esquema filosófico.

Los puntos relevantes en función del concepto de libertad son los siguientes. En primer lugar, Schelling intenta llevar a cabo el programa de una "construcción histórica del cristianismo" (51). Ello implica que "el carácter fundamental" de este es la concepción del "universo en general como historia, como reino moral" (52). Lo cual supone, por de pronto, que Dios se revela no simultáneamente, en la naturaleza, como ocurría en las religiones previas al cristianismo, sino sucesivamente, en la historia, cada uno de cuyos momentos particulares representa la "revelación de un momento particular de Dios, quien es absolutamente en cada uno de ellos" (Jeder besondere Moment der Zeit ist Offenbarung einer besonderen Seite Gottes, in deren jeder er absolut ist) (53). "Lo divino ha dejado de revelarse en la naturaleza y es cognoscible (erkennbar) solo en la historia" (54). La raíz de este cambio de perspectiva está en la maduración de la conciencia que hace que lo determinante no sea el ser, la naturaleza, lo real, sino lo ideal y predominantemente la historia, "en la que lo divino se despoja de su cáscara (legt das Göttliche die Hülle ab)" (55).

La desacralización de la naturaleza supone que el hombre se ha distanciado, rompiendo la relación de inmediatez con ella y convirtiéndola en objeto de actuación. Esta ruptura ha de ser subsanada mediante la restauración de la unidad en un plano distinto, caracterizado por una toma de conciencia tanto de la distinción como de la

(47) Cf. W. Schulz, Die Vollendung des Deutschen Idealismus in der Spätphilosophie Schelling, Pfullingen ${ }^{2} 1975$.

(48) Cf. para ello la excelente monografía reciente de P. Trawny, Die Zeit der Dreieinigkeit. Untersuchungen zur Trinität bei Hegel und Schelling, Würzburg 2002.

(49) Cf. J. Noemi, Jesucristo, 138-140.

(50) Remito para esta compleja temática a las importantes contribuciones de J. Noemi al respecto, cf. Los fundamentos de una teología de la libertad, Teología y Vida 22 (1981), 3-15.

(51) Tal es el título de la octava lección de su escrito Vorlesungen über die Methode des akademischen Studiums (1803), en: Ausgewählte Werke, Schriften von 1801-1804, Darmstadt 1966, 411-586 (versión en español: Lecciones sobre el método de los estudios académicos, Madrid 1984).

(52) Ibíd., 521.

(53) Ibíd., 522.

(54) Ibíd., 523.

(55) Ibíd. 
mutua pertenencia. En este sentido la libertad se revela, por una parte, como vencida (besiegt), en tanto que implica sumisión a la naturaleza, y por otra, como vencedora (siegend), porque es una sumisión no ciega ni inconsciente, sino libremente aceptada y proyectada, y porque significa que la necesidad que domina la naturaleza es instrumentada al servicio de la necesidad propia de la acción histórica. La historia no se sustrae en modo alguno al "orden eterno de las cosas" (56). El individuo y la acción correspondiente no son sino "instrumento de la necesidad absoluta". Pero esta no es una necesidad ciega (naturaleza), ni una necesidad en conflicto con la libertad (destino), sino providencia que postula una "conciliación consciente" con la necesidad (57). Expresión de tal conciliación es "el Dios hecho hombre", cuyo verdadero significado está en que "lo infinito verdadero ha venido a lo finito, no para divinizarlo, sino para ofrendarlo a Dios en su propia persona y así conciliarlo (daß das wahre Unendliche in das Endliche kam, nicht um dieses zu vergöttern, sondern um es in seiner eignen Person Gott zu opfern und dadurch zu versöhnen)" (58).

Schelling tuvo que darse cuenta de que este primer planteamiento adolecía de dos limitaciones. De una parte, por más que acentúa la contraposición entre naturaleza e historia, esta se revela en el fondo como naturalizada, al no ser sino expresión del "orden eterno y absoluto de las cosas", es decir, de una naturaleza originaria. Había, pues, que repensar dicho orden, no solo como eminentemente activo (ordo ordinans), sino como dotado de una libertad originaria. Por otra parte, la persona de Cristo aparece reducida de hecho a una especie de expresión simbólica del orden cósmico en uno de sus estadios, como "límite de dos mundos", es decir, como culminación del mundo antiguo y a la vez como origen del nuevo, al que da paso, pero en el que propiamente no entra, pues lo que de él queda es el "espíritu, el principio ideal". Schelling intentará más tarde situar la persona de Cristo en el centro de la historia, en lugar de verla como un mero estadio de ella.

En cuanto al primer aspecto, sus especulaciones a partir del escrito Investigaciones filosóficas sobre la esencia de la libertad humana (1809) (59), tienden a introducir en el principio absoluto una estructura dual, antitética y recíproca a la vez, que posibilita la originación espontánea de una serie de formas de ser, en las que se va a ir configurando. Lo que impugna decididamente en este contexto es cualquier tipo de emanatismo (60), incluida la idea cristiana tradicional de creación. El emanatismo implica la admisión de un proceso descendente, en el que se van perfilando manifestaciones cada vez más imperfectas de la divinidad. Schelling propone la inversión de este esquema. El principio absoluto es una "fuerza originaria" (Urkraft), que se va configurando en un proceso ascendente según formas cada vez más perfectas, variadas y concretas llamadas a transfigurarse finalmente en una "personalidad suprema", que no parece ser sino Cristo como culminación del proce-

(56) Ibíd., 526.

(57) Ibíd., 524.

(58) Ibíd., 526.

(59) Id., Philosophische Untersuchungen über das Wesen der menschlichen Freiheit und die damit zusammenhängenden Probleme (1809), en: Ausgewählte Texte, Schriften von 1806-1807, Darmstadt 1968, 275-360 (versión en español: Investigaciones filosóficas sobre la esencia de la libertad humana, Barcelona 2002).

(60) Cf. J. Noemi, Jesucristo, 142. 
so histórico de autorrealización de Dios (61). Cristo sería ahora una especie de punto omega del proceso cósmico, que se va concretando en una complicada relación entre deidades y hombres (62).

Pero con ello, si bien se realza la figura de Cristo, aparece desdibujada la persona histórica y concreta de Jesús de Nazaret, tanto más cuanto que Schelling piensa aún en una racionalización completa del cristianismo. Aunque no parece que lograra una rehabilitación perfecta de tal dimensión, al menos intentó hacerlo en el marco de una revisión de sus planteamientos anteriores, que le llevan a una "filosofía positiva", en la que se relativiza el alcance de lo estrictamente racional y se concede un relieve especial a lo fáctico y a lo concretamente histórico. En sus lecciones sobre Filosofía de la revelación de 1841-1842 (63) afirma que "todos los tesoros del conocimiento están ocultos en Cristo, es decir, están comprendidos en él. Tienen que ser comprendidos con él, de lo contrario él no es comprendido... Él es el fin del saber; quien le tiene en verdad y le conoce por completo, tiene con él y en él todo el saber". En el contexto esta afirmación implica, entre otras cosas, la insuficiencia de la acción creatural y la necesidad de restablecer el sentido del mundo "mediante la acción decisiva de una voluntad supracreatural y, sin embargo, humana" (64). La acción de Jesús de Nazaret abre perspectivas trascendentes a la razón, como se muestra, por ejemplo, en el precepto del amor a los enemigos. La tarea fundamental que expresa el significado y alcance de la persona y de la vida de Jesús de Nazaret es la redención. "En la creación muestra Dios su espíritu; en la redención, su corazón" (65). Ello implica un abandono del poder, que es lo propio del espíritu, y una asunción de la debilidad. "Solo el fuerte puede ser débil" (66). Como pertinentemente comenta Kasper este axioma: "Solo podemos hacer alusión en este momento al hecho de que, para Schelling, la divinidad de Dios, que es su absoluta libertad, ofrece también la posibilidad, al soportar su propio contrario, de mediar el devenir histórico de Dios, de modo positivo, con la eternidad de Dios" (67). Desde estos planteamientos se abren perspectivas nuevas para valorar el acontecimiento salvífico de la muerte y de la resurrección de Cristo (68).

4. Hegel: Cristo o la necesidad de una filosofía del espíritu. La verdad de la filosofía queda afectada por el significado de Jesús de Nazaret (69)

En el tema que nos ocupa, al igual que en tantos otros, Hegel representa la culminación de los planteamientos iniciales históricamente tanto por la amplitud de

(61) F. W. J. Schelling, Über die Gottheiten von Samothrace (1815), en: Ausgewählte Werke, Schriften von 1815-1830, Darmstadt 1968, 164-165.

(62) Cf. W. Kasper, Cristo y nuevo planteamiento, 204ss (con referencia a los planteos de Teilhard de Chardin y Bloch).

(63) Philosophie der Offenbarung 1841-1842, (ed. M. Frank), Frankfurt 1977.

(64) Ibíd., 254.

(65) Ibíd., 257; cf. la importante obra de E. Brito La Création selon Schelling, Lovaina 1987.

(66) Philosophie der Offenbarung, 256.

(67) Crisis y nuevo planteamiento, 210.

(68) Cf. Philosophie der Offenbarung, 299-307.

(69) Cf. las investigaciones fundamentales del filósofo de Lovaina E. Brito, Hegel et la tache actuelle de la Christologie, Paris 1979 y La Christologie de Hegel. Verbum crucis, Paris 1983. 
las cuestiones que aborda como por la profundidad de la exposición, y sobre todo porque, en lo que es el núcleo fundamental, extrae todas las consecuencias. No es extraño que la investigación sobre la relevancia de Cristo para la filosofía se haya centrado en su obra de forma especial. Aquí nos limitaremos a poner de relieve el modo en que Hegel asume la interpelación que implica Cristo para su filosofía.

Se cumple en él, en mayor grado que en los autores expuestos hasta ahora, que la verdad de su filosofía queda afectada por lo que significa Jesús de Nazaret (70). No elabora una filosofía que luego aplica a Cristo bajo estos o aquellos aspectos, sino que la formación de su filosofía la lleva a cabo bajo puntos de vista en los que la referencia a los orígenes del cristianismo, y más concretamente a la vida y obra de Cristo, resulta esencial. Sabido es que en una primera etapa, que dura algo más de veinte años, Hegel se ocupa de esas cuestiones con especial intensidad y que en la época de Jena, como consecuencia de reiteradas reflexiones, llega a la convicción de que el cristianismo es la religión absoluta, cuyo contenido fundamental adquiere realidad efectiva en la persona individual, sensible y concreta de Jesús de Nazaret (71). En la Fenomenología del Espíritu están ya trazadas las líneas básicas de su concepción y, sobre ese supuesto, por una parte dejará claramente reflejado en las diferentes ediciones de la Enciclopedia el lugar de la religión en el sistema y, por otra, intentará hacer en la serie de Lecciones de los años veinte cómo las diferentes religiones cobran sentido y legitimidad desde el cristianismo, además de analizar desde diferentes perspectivas la figura de Cristo. De la mano de un eximio conocedor de Hegel como lo es M. Theunissen, se puede sintetizar esto así: "En virtud del carácter desbordante de su espíritu Dios se sitúa en el centro. El centro es el mediador que media a los hombres con Dios y, de esa manera, a Dios consigo mismo. De acuerdo con nuestra introducción sistemática, Hegel concibe a Cristo como el centro de la historia, así como, de acuerdo ahora con los capítulos fundamentales de la investigación presente, también como el centro lógico y, de acuerdo con los capítulos finales, como el centro del reino de Dios que irrumpe en su figura, y que en palabras de san Lucas se encuentra 'en medio' de nosotros. La completa explanación del centro no apunta, pues, sino a la radicalización del planteamiento cristológico de partida con el que el propio Hegel inaugura y pone fin a su reflexión” (72).

Aquí comentaré, brevemente, dos páginas de la Fenomenología, en las que aparece claramente la vinculación de la concepción filosófica de Hegel con su reflexión sobre el significado y alcance de la persona de Cristo. Tres ideas tan fundamentales en Hegel como que lo verdadero es no solo una sustancia, sino sujeto (73), sobre la proposición especulativa (74) o el nuevo modo de entender la relación entre lo absoluto y sus manifestaciones (75), están presentes en el texto. Se encuentran

(70) Así por ejemplo Hünermann en su Cristología se refiera al "sistema filosófico hegeliano, cuya clave es un concepto de espíritu de impronta cristológica" (404); luego habla que "el conjunto del sistema [hegeliano] tiene a la cristología como su centro vertebrador" (Ibíd., ver además 405-409).

(71) Cf. G. W. F. Hegel, Jenaer Systementwürfe III, Naturphilosophie und Philosophie des Geistes, (ed. R.-P. Horstmann), Hamburg 1987, 257ss.

(72) Hegels Lehre vom absolutem Geist als theologisch-politischer Traktat, Berlín 1970, 58.

(73) Phänomenologie des Geistes (versión en español: Fenomenología del espíritu, México 1966), 19.

(74) Cf. Ibíd., 50ss.

(75) Cf. Ibíd., 14ss. 
también en otros lugares, lo cual no debe sorprender, puesto que se trata de ideas fundamentales. Pero llama la atención que estén las tres en un texto tan breve, que estén de forma tan clara y, sobre todo, que las tres aparezcan en el momento en que Hegel quiere dar cuenta de la "Encarnación (Menschwerdung) de la esencia divina", lo cual legitima la conjetura de que la reflexión sobre esta creencia -que debe ser comprendida y, solo en cuanto comprendida, superada- tiene lo suyo que ver con el nacimiento y elaboración de aquellas ideas.

Para comenzar, Hegel centra el contenido de la religión absoluta en la Encarnación -el término alemán "Mensch-werdung" significa que Dios ha devenido o se ha hecho hombre-, más concretamente en el hecho de que la esencia absoluta tiene "la figura de la autoconciencia (Die Gestalt des Selbstbewußtseins)" (76). Esto no tiene en principio nada de extraño si se tiene en cuenta que el protestantismo, al que Hegel pertenecía con plena convicción, ha centrado la teología en la cristología, ha hecho de ella su "gramática" (77). Pero dicho contenido es el "contenido simple", lo cual implica que todo otro contenido se reduce a él y se explica desde él. Lo cual, como veremos, implica -desde la radicalidad con que Hegel plantea la cuestión- que Dios llega a ser verdadera y plenamente Dios en Cristo.

Que la esencia divina tiene la figura de la autoconciencia significa que "la esencia es sabida como espíritu", lo cual encuentra su explicación en que "el espíritu es el saber de sí mismo en su exteriorización" (Denn der Geist ist das Wissen seiner selbst in seiner Entäußerung) (78). Es decir, no basta con que el espíritu reflexione o vuelva sobre sí, más aún, esto no lo puede lograr sino en cuanto que se exterioriza y retiene "en su ser-otro la igualdad consigo mismo" (in seinem Anderssein die Gleichheit mit sich selbst) (79). Lo cual encierra tres aspectos, que en conjunto suponen una modificación esencial de la noción de espíritu, que históricamente se había venido preparando desde los orígenes del pensamiento moderno, pero que culmina en Hegel. En primer lugar, la esencia en cuanto espíritu no posee propiamente una igualdad consigo misma que simplemente mantiene en cada una de sus manifestaciones. Es lo contrario, la esencia tiene tal igualdad porque y en cuanto que la mantiene en dichas manifestaciones. Lo cual supone que la esencia en cuanto espíritu propiamente no es ya, sino que es "el movimiento consistente en retener en su ser-otro la igualdad consigo misma” (80). En segundo lugar, la consecuencia inmediata es que en el ámbito de la esencia como espíritu, el ser-otro es su ser-otro, el que corresponde al espíritu, por lo cual la alteración de la esencia -y la consecuente alteridad- no es un debilitamiento, un progresivo ir a menos del espíritu, sino constitutivamente su enriquecimiento, lo que él desde sí mismo exige para llegar a ser plenamente. Y en tercer lugar, lo uno y lo otro revelan una inversión en la forma de concebir la sustancia, lo que propia y auténticamente es. Resultaba habitual -y no solo en la tradición aristotélica- considerar la sustancia frente a lo accidental y lo accidental frente a la sustancia, como si los accidentes fueran "algo

(76) Ibíd., 528.

(77) Cf. I. Dalferth, Der auferweckte Gekreuzigte. Zur Grammatik der Christologie, Tübingen 1994.

(78) Phänomenologie, 528.

(79) Ibíd.

(80) Ibíd. 
que es inesencial (Unwesentliches) y que por ello se encuentra en algo extraño (Fremden)". La accidentalidad existe, sin duda, pero en esa su accidentalidad la sustancia "está reflexionada hacia sí", cabe decir, que la sustancia se refracta en los accidentes y, al hacerlo, está volviendo hacia sí. Esto implica a su vez que la sustancia, a la par que penetra en los accidentes, es en sí misma, con otras palabras, "sujeto o mismidad" (Subjekt oder Selbst) (81).

Esta idea central, consistente en considerar a la sustancia "también y en la misma medida como sujeto", tiene su raíz última en la esencia en tanto que es espíritu, porque es aquí donde la dimensión sujetual de la sustancia llega a su culminación. Y a su vez esto es lo que, en el orden de la realidad efectiva, se da ante todo en la religión absoluta, que es la religión cristiana: "En esta religión está, pues, revelada (geoffenbart) la esencia divina. Su ser-manifiesto (Offenbarsein) consiste manifiestamente (offenbar) en que es sabido lo que esa esencia es. Ahora bien, es sabida en cuanto que es sabida como espíritu, como esencia, que es esencialmente autoconciencia" (82). Ahora se comprende mejor el sentido de lo que anteriormente hemos visto sobre la esencia. La religión cristiana es revelada, no simplemente porque en ella "la esencia divina" da a conocer estos o aquellos contenidos, permaneciendo ella oculta, sino porque ella misma se manifiesta. Esto, a su vez, solo tiene sentido si se la conoce en cuanto espíritu, o lo que es lo mismo, en cuanto autoconciencia. La respuesta a la eventual pregunta acerca de por qué tiene que ser así, es decir, por qué no puede ser conocida de otro modo, es obvia: porque solo la autoconciencia es lo manifiesto. Pero esto requiere una consideración más concreta, como es la que proporciona Hegel en las líneas que siguen.

Uno puede preguntar obviamente por qué no basta con que Dios se muestre como un "objeto" para la conciencia. La respuesta en este caso es que a la conciencia le pueden ser patentes muchas, infinitas cosas, y sin embargo estas cosas le están presentes como "algo otro o extraño", o dicho de otra forma, si la conciencia, al conocer el objeto en cuestión, "no lo sabe como sí misma" (83), lo conocerá como algo otro, extraño. Puede la conciencia conocer muchas cosas con claridad y al mismo tiempo moverse de oscuridad en oscuridad, sobre todo si se da la oscuridad fundamental, el desconocimiento de sí misma. La única forma de que la conciencia supere esa opacidad estriba en que el objeto conocido sea "sí mismo" (Selbst), porque solo tal mismidad no es nada extraño. Todo lo que no sea esto equivale a quedar expuesto al ser oculto o secreto, a permanecer pendiente de lo otro o extraño. "Este ser-secreto termina, en cuanto que la esencia absoluta, como espíritu, es objeto de la conciencia" (84). ¿Por qué razón el "sí mismo” del hombre no puede considerar extraño al "sí mismo" propio de Dios, y por qué no se puede considerar a sí mismo como extraño respecto de ese otro "sí mismo" que es Dios? Porque y en cuanto que "el sí mismo no es algo extraño, sino la unidad inseparable consigo, lo inmediatamente universal" (85). Esto es lo peculiar del

(81) Ibíd.

(82) Ibíd.

(83) Ibíd.

(84) Ibíd.

(85) Ibíd. 
pensamiento como tal: "ser para sî" y al mismo tiempo "ser para otro", en definitivas, esencial comunicación y con ello libertad o ser "consigo mismo (bei sich Selbst)". Así se entiende el sentido de lo que Hegel repite incansablemente, sobre todo a partir de ahora: que el espíritu es para el espíritu. Solo supuesta esa comunicación, sentencia Hegel, "estamos ante lo verdadera y exclusivamente manifiesto" (86). Se opera frecuentemente con el prejuicio de que Hegel pretende saberlo todo cuando habla de algo, en este caso de la religión. Y es ciertamente complejo y dificultoso su empeño. Pero lo que le mueve es un afán de simplicidad, de búsqueda de lo esencial. Basta para comprenderlo así tener presente que el punto de referencia es la autoconciencia, ese ámbito en que la conciencia es transparente a sí misma.

Esto se pone tanto más de manifiesto si se hace más explícita la referencia a Dios bajo el punto de vista de la proposición especulativa. Al hablar de Dios se le atribuyen determinados predicados: lo bondadoso, lo justo, lo santo, creador de cielo y tierra, etc. Son predicados de un sujeto en el que tienen su soporte. Por el hecho de que dichos predicados sean válidos no es aún manifiesto lo que es su fundamento y su esencia, el sujeto mismo. Por el hecho de hablar de Dios en términos de bondad, sabiduría, etc., podemos llegar a saber mucho de estos predicados, pero de forma que el sujeto queda definido en ellos sin que propiamente se nos desvele como tal sujeto. Se conocen "momentos universales", incluso "determinaciones de lo universal en cuanto que los predicados se consideran como sustentados en un soporte que tiene un alcance universal, pero no "este universal mismo", puesto que aquellos no son un "este" (Dies). Si los predicados son universales, su soporte tiene que ser también universal, pero al mismo tiempo tiene que ser en verdad sujeto, un "este", que es simultáneamente universal (87). "Pero el sujeto mismo y con ello también este universal puro es manifiesto en cuanto sí mismo, pues este sí mismo es precisamente esto interior reflejado en sí, que existe de modo inmediato" (88).

La proposición especulativa consta, pues, según este contexto, de dos fases: en la primera de ellas lo que es el sujeto, Dios en este caso, queda expresado en sus predicados. Pero es necesario que en una segunda fase sea conocido el sujeto mismo en cuanto tal, lo cual significa tanto que es preciso conocerlo en cuanto fundamento y esencia de los predicados como que es preciso verlo en sí mismo, en cuanto que es un "este universal". Tal conocimiento solo se puede dar en cuanto que el sujeto aparece como sí mismo, ya que solo así se hace manifiesto. Ahora bien, lo que se añade explícitamente aquí y no aparece en algún otro lugar, en que se habla de la proposición especulativa en su referencia a Dios, es que ese sí mismo solo se hace manifiesto, si lo es para la conciencia, en cuanto que esta se relaciona con aquel en calidad de autoconciencia y por tanto como sí mismo también. Esto es lo que ahora expresa también Hegel al decir que "esto interior reflejado en sî", que es en definiti-

(86) Ibíd.

(87) Cf. para esta temática y en general para la problemática de la cristología en Hegel, la segunda parte de M. Borghesi, L'ètá dello Spirito in Hegel. Dal Vangelo "storico" al Vangelo "eterno", Roma 1995.

(88) Phänomenologie, 529. 
va Dios mismo en cuanto sujeto de sus predicados, "es la propia certeza de aquel sí mismo, para el que es ahí" (89). Es decir, Dios, en cuanto que se manifiesta como autoconciencia representa nada menos que la autoconciencia que el hombre posee, o dicho de otro modo, si el hombre es un sí mismo, es autoconciencia porque y en tanto que la esencia divina se ha hecho realidad en él.

Por este procedimiento llega Hegel a la afirmación de la identidad de la naturaleza divina y de la naturaleza humana. Antes de aducir el texto relativo a esta identidad conviene tener presente que, si ya en la historia del pensamiento cristiano se había producido la superación del concepto aristotélico de Dios, que deja de estar solo vuelto sobre sí mismo, ahora se llega, por el procedimiento que hemos venido siguiendo, a la legitimación filosófica del concilio calcedonense, que explícitamente enseña la unidad de la naturaleza divina y de la humana en un mismo sujeto o persona (90). Hegel, consciente de la gravedad de su pretensión, se expresa, a la vez que alude a lo ya expuesto, del modo siguiente: "Esto -el ser según su concepto lo revelado (das Offenbare) - es, pues, la verdadera figura del espíritu, y esta su figura, el concepto, es también exclusivamente su esencia y sustancia. Él (el espíritu) es sabido como autoconciencia y está inmediatamente revelado a esta, pues es esta misma; la naturaleza divina es lo mismo que la humana, y es esta unidad la que es intuida" (91). Que el espíritu sea lo revelado o manifiesto según su concepto, quiere decir que por su naturaleza está llamado o destinado a serlo. En este caso esa revelación se produjo cuando llegó el tiempo oportuno o "la plenitud de los tiempos" (Gal 4, 4). Hegel tiene en efecto muy presente que el espíritu como desvelación de la esencia divina entra en la historia con el cristianismo (92).

Por otra parte, ese concepto ya realizado es él solo, "su esencia y sustancia". Es decir, no hay, real y efectivamente, primero un espíritu ya plena, esencial y definitivamente constituido que luego, en un momento dado, opta por manifestarse, sino que su esencia y sustancia no consiste sino en esa su manifestación. Esto supuesto, y dado que esa manifestación consiste en él "sí mismo" o "mismidad" (Selbst), que como tal es revelación a la autoconciencia, lo es en la forma de ser idéntico con ella, pues de otra forma se mantendría algo oculto, al menos en parte, y no se cumpliría lo que el concepto exige, su revelación plena. Y es aquí donde, terminológicamente hablando, Hegel da el salto para decir algo que estaba solo implícito en lo anterior: "que la naturaleza divina es lo mismo (dasselbe) que la humana". Es decir, la esencia divina que es autoconciencia y, como tal, espíritu que se manifiesta plenamente, y en cuanto espíritu a su vez, "sí mismo" (Selbst), se comunica al sí mismo que es el hombre, es en realidad idéntico con él. Que sean idénticas ambas naturalezas no significa que se confunda la una con la otra. Se trata de la identidad concreta, que salvaguarda la diferencia, pero dentro de una relación caracterizada por el movimiento de esencial comunicación entre ambas naturalezas (93). Esa diferencia se salvaguarda además,

(89) Ibíd.

(90) Cf. DH 302.

(91) Phänomenologie, 529.

(92) "EI contenido de la religión cristiana consiste en dar a conocer a Dios como espíritu" (Enzyclopädie der philosophischen Wissenschaften im Grundrisse [1830], Hamburg 1991, § 384).

(93) Cf. Phänomenologie, 539-542. 
según este mismo contexto, en cuanto que la unidad de naturaleza divina y naturaleza humana "es intuida", pues tal intuición se da en cuanto referida a una persona sensible y concreta, la de Jesús de Nazaret. Es lo que aparece más claro en lo que sigue.

Hegel asume de lleno, dentro de su peculiar esquema de interpretación, la concepción paulina, según la cual (Flp 2, 7) Cristo "se despojó de sí mismo" (94). Reconoce Hegel que para la conciencia, Dios, a la par que autoconciencia, "tiene igualmente de modo inmediato el significado del pensamiento puro, de la esencia absoluta" (95). Con ello parece volver a la posición de la teología, que en realidad da por válida, en lo fundamental, la concepción aristotélica sobre la naturaleza de Dios (96). Pero en realidad va a llevar a cabo en pocas líneas, con la referencia inequívoca a San Pablo, una superación (aufheben) de la misma: "La esencia absoluta, que existe como una conciencia efectivamente real, parece haber descendido de su simplicidad eterna, pero con ello ha alcanzado (erreicht) de hecho solo así su esencia suprema" (97). Es cierto que esta afirmación no parece fácilmente compatible con la forma en que la teología ha venido entendiendo la encarnación, considerada como donación gratuita de Dios, absolutamente perfecto desde toda la eternidad. No es menos cierto que, como ocurre en toda interpretación especulativa, están en juego determinados conceptos, casi nunca desvelados por completo, aspecto sobre el que volveremos.

La forma en que aquí fundamenta Hegel su afirmación se reduce a que Dios, considerado como "pensamiento puro", implica en sí la referencia al ser, puesto que no hay pensamiento que no sea pensamiento del ser, y "lo que se llama conciencia sensible" nos pone ante esa doble dimensión: el pensamiento puro y "lo inmediato o el ser". Es, con otras palabras, lo menos, lo más elemental que puede hacer la llamada conciencia sensible: pensar el ser, que le viene dado de forma inmediata. Y teniendo en cuenta que la conciencia sensible está considerada como el nivel más bajo o elemental de la actividad de la conciencia, concluye Hegel: "Lo más bajo (das Niedrigste) es, por tanto, al mismo tiempo (zugleich) lo más alto (das Höchste); lo revelado, que ha aparecido totalmente en la superficie (an die Oberfläche) es, precisamente de este modo, lo más profundo (das Tiefste). Que la esencia suprema sea vista, oída, etc. como una autoconciencia existente, esto es, pues, de hecho la consumación de su concepto; y mediante esta consumación la esencia está inmediatamente ahí (unmittelbar da) tal como es esencia" (98). Aquí no vamos a intentar una comparación con el texto de Pablo, que parece estar muy presente en las palabras de Hegel. Por lo que se refiere a la fundamentación, que acabamos de mencionar, tampoco vamos a entrar en una explicación de la misma, porque exigiría nada menos que una aclaración de conceptos tan fundamentales como pensar, ser, inmediatez, abstracción (que en este caso hace referencia a la realidad tanto de Dios como del hombre en su grado más elemental, etc.). Lo cierto es que Hegel se siente muy seguro en lo que afirma, y lo que cabe conjeturar como muy probable es que en

(94) Hegel utiliza aquí la idea de "Entäußerung"; cf. P. Hünermann, Cristología, 412ss.

(95) Phänomenologie, 529.

(96) Aristóteles, Met. XII, cc. 7-9.

(97) Phänomenologie, 529, cf. además 539.541.

(98) Ibíd, 529. 
su concepción de la lógica, al exponer los conceptos de pensar y de ser, tuviera también en cuenta "la encarnación de la esencia divina".

Es legítimo decir que estamos ante una "transinterpretación (Umdeutung) de la idea tradicional de la condescendencia” (99). Con otras palabras, según la teología tradicional, Dios, sin menoscabo de su perfección absoluta desde toda la eternidad, se ha hecho hombre en la persona de su Hijo, que ha asumido libre y gratuitamente la naturaleza humana, a la que de este modo eleva a una dignidad infinita. Hegel, por el contrario, habría afirmado también la perfección de Dios "según el concepto", pero tal perfección habría llegado a su completa realización en la persona sensible, individual, concreta e histórica de Jesús de Nazaret. Lo que por otra parte parece innegable es que a esta realidad histórica asocia Hegel un "nuevo comienzo". Desde ese comienzo nuevo es capaz de retener, a la par que de superar radicalmente, la concepción aristotélica de Dios (100).

La cuestión que ahora cabe plantear es si, dando por supuesta la aportación hegeliana en cuanto a la interpelación esencial de la filosofía por parte de la persona y la obra de Cristo, cabe retomar hoy esa cuestión desde una perspectiva diferente.

\section{RECONSIDERACIÓN SISTEMÁTICA-ONTOLÓGICA DE LA PRETEN- SIÓN MISIONAL DE PROCLAMAR A CRISTO COMO EXIGENCIA UNIVERSAL DE VERDAD.}

1. Revisar la concepción de verdad. Paso previo indispensable para repensar la problemática de la relación entre lo absoluto y lo contingente en clave cristológica en la teología.

En lo antes expuesto (I), se analizó la empresa de intentar comprender el cristianismo desde un planteamiento filosófico determinado, lo cual implica verlo en sintonía con el pensamiento como tal. Ahora bien, pensar algo es ver su necesidad, y a esta se la asocia con la falta de libertad. ¿Cómo entonces pensar el cristianismo, si se supone que este es fuente y garantía de libertad? La razón, sin embargo, y con ella la necesidad de que aquí se trata, no es coactiva, o simplemente restrictiva e impositiva, sino expresión de un orden en que cada cosa encuentra su acomodo, exhibe su ser en tanto que abierto al de todas las demás cosas, y se muestra dando de sí y desplegándose en su propio ámbito hasta el límite de sus posibilidades. En este sentido, la necesidad no solo no se opone a la libertad, sino que, más allá de ser simplemente compatible con ella, es libre en su raíz en cuanto expresión de la espontaneidad del ser mismo. Por eso Dios es libre interna y esencialmente en sí mismo y no solo respecto del mundo y del hombre: porque los haya creado, pudiendo no haberlos creado, o porque los haya hecho de tal forma, pudiendo haberlos hecho de otra. La necesidad que acompaña a la razón tiene que ver con ese orden

(99) R. Maurer, Hegel und das Ende der Geschichte, Stuttgart 1965, 77.

(100) Sobre la cuestión de Dios en Aristóteles y Hegel, cf. Th. de Konninck-G. Planty-Bonjour (eds.), La question de Dieu selon Aristotele et Hegel, Paris 1991. 
interno del ser y apunta por tanto a la libertad entendida como plenitud de ser, no como indeterminación, indiferencia, y mucho menos como arbitrariedad (101).

Pensar el cristianismo es dar razón del acontecimiento fundamental que es Cristo mismo, su "esencia" (Wesen) como señala Von Harnack, y de la forma como ese hecho se ha configurado y ha otorgado sentido a los períodos anteriores y posteriores a él. Como bien indica Schelling en la Filosofía de la revelación: "Cristo no es el maestro, como se suele decir, Cristo no es el fundador (Stifter), Él es el contenido del cristianismo (der Inhalt des Christenthums)" (102). Con esta tesis, señala Kasper, Schelling traza la línea divisoria con la escolástica, a la que le reprocha el haber arrancado a la teología de su terreno natural, el histórico, y el haberla transformado en una doctrina casi completamente ahistórica (103). Por esto no puede tratarse de una razón abstracta (104). En referencia a hechos y acontecimientos, la razón tiene que narrarlos, descubrir y explicitar sus contornos, dejarlos y hacerlos ser lo que son, mostrar su sentido. Como nos recuerda Ricoeur: "No hay acontecimiento más que para quien puede narrarlo, hacer memoria de él, crear archivo y relato" (105). La razón tiene que ser por ello narrativa e histórica a un tiempo. Propiamente no se trata de que, además del logos, al que ha estado unido desde el comienzo el destino de la filosofía, se den la narración y la historia, sino de que haga su aparición el logos que es interno e inmanente a aquellas (106). Cuando en estas reflexiones hemos hablado de que Cristo, un personaje contingente, implica una exigencia de verdad, esta -y que a su modo está en el mismo horizonte en que se mueven los filósofos que han tomado en serio la persona y la obra de Cristotiene muy poco que ver con las diferentes teorías actuales acerca de la verdad (107), algunos de cuyos máximos representantes son, por ejemplo, Tarski, Mackei, Williams y Rescher. Todas ellas presuponen que hay algo y la constatación de ese algo, y a partir de ahí se ocupan de si nuestras representaciones se corresponden con lo que hay, de cómo podemos tener la certeza de que es así, qué significa, con precisión, esa correspondencia (es la verdad como correspondencia, la falsedad como lo contrario; la fórmula adaequatio rei et intellectus se atribuye al filósofo judío del siglo noveno Isaac Israeli (108)), cómo se salvaguarda la coherencia de los diferentes enunciados, cómo se posibilita la comunicación de esa verdad y se logra eventual-

(101) Cf. A. Gesché, La libertad como invención y creación, en: Dios para pensar, vol. VII, El Sentido, Salamanca 2004, 29-58.

(102) Der Philosophie der Offenbarung, Drittes Buch, en: Werke [ed. K. F. A. Schelling], vol. XIV, Stuttgart 1841-1854, 35. Ver también K. Lehmann, Absolutheit, 35ss.

(103) Cf. Cristo y el nuevo planteamiento, 198.

(104) Cf. K. Lehmann, Absolutheit, 34ss.

(105) Temps et récit, vol. 3, Paris 1985, 353.

(106) Cf. id., Lectures, vol. 3, Aux frontières de la philosophie, Paris 1994. Un ejemplo de recepción creativa en la cristología católica actual de Ricoeur se advierte en A. Gesché, Dios para pensar, vol. VI, Jesucristo, Salamanca 2002, especialmente 59-136.

(107) Cf. L. B. Puntel, art. Verdad, en: H. Krings et al. (ed.), Conceptos fundamentales de filosofía, vol. III, Barcelona 1979, 616-637; J. Szaif et al, art. Wahrheit, en: J. Ritter et al (ed.), Historisches Wörterbuch der Philosophie, vol. 12, Basel 2004, 48-123, sobre todo 103-123.

(108) El significado de esta fórmula se retrotrae a Aristóteles Met. IV, 7, 111b, 26-28 y a la tradición medieval, que utilizó términos más o menos afines para expresar la misma idea: adaequatio, correspondentia, conformitas, consonantia, conmensuratio, etc. 
mente un consenso sobre su significado, etc. Se eluden así en estas teorías los problemas, presuntamente metafísicos, que son inherentes a la verdad como correspondencia y se logran fórmulas simplificadas del tipo "x es verdadera si p", "nieva es una proposición verdadera si y solo si nieva".

Tales cuestiones dan por supuesto que algo es o existe, pero no se preguntan por el significado que tiene el hecho de que exista, por el significado del ser. Tan obvio y natural parece ser ese hecho que preguntar por su sentido se considera como no pertinente. Como tampoco sería pertinente el segundo aspecto que aquí nos interesa: a qué responde el ser, cómo se corresponde con su propia esencia, con el arquetipo o ideal que todo ser lleva grabado en sí mismo. Y por último, queda igualmente marginado un tercer aspecto: cómo lo esencial se desvela y se hace o constituye como verdadero en esa su desvelación. Para decirlo en términos convencionales, tenemos que ver, a contracorriente de lo que hoy prevalece en las teorías sobre la verdad, con el ser, la esencia y el sentido (109).

Aquí hay que detenerse, aunque solo sea sinópticamente, en el complejo tema de la verdad, pues él nos servirá para mediar entre los dos polos de la problemática de nuestras reflexiones: lo absoluto y lo contingente: ¿qué tipo de definición de verdad es la más adecuada para permitir la intelección del acontecimiento cristológico y dejar a su vez que este amplíe a aquella? La problemática, que ya hemos anticipado, se debe al uso no pocas veces acrítico de la verdad como "correspondencia" en el ámbito teológico, y que ha sido puesta en cuestión profundamente por la filosofía actual.

La verdad como correspondencia provoca, entre otras, una dificultad desde dos ángulos complementarios. Si la mente $-\mathrm{o}$ algo que tenemos en la mente- se ha de corresponder o adecuar a las cosas -a cada cosa en cuestión-, parece presuponerse que las cosas están ya definitivamente cerradas o clausuradas, sin que por tanto quepa esperar nada nuevo (el Novum de Bloch, la apertura a lo novedoso sin la cual no somos verdaderamente humanos; como afirma García-Baró: "Existir es una constante revelación" (110)). Más bien, habría por principio que excluir todo lo nuevo. Esta misma actitud excluyente vendría reforzada desde la perspectiva opuesta, en cuanto que se pretende aplicar a las cosas un concepto, como medida a la que aquellas tienen que ajustarse. Con ello queda por principio excluido o rechazado todo aquello que no se ajuste a tal medida. Ambas perspectivas -que la cosa es ya, o expresa simplemente, algo clausurado en sí, y que la cosa es o no es, vale o no vale, y en definitiva es o no es verdadera en la medida en que se ajusta al concepto como su medida-, vienen a expresar lo mismo: la identificación de lo verdadero con un ámbito determinado y la exclusión de su contrario, de lo que se considera como falso. Por otra parte, esto mismo viene favorecido por la concepción de la negación como desvinculada de la afirmación. De hecho, en la filosofía, como actividad que

(109) Tres libros recientes nos hacen pensar en este sentido: las atinadas y profundas reflexiones del fenomenólogo español M. García-Baró, El dolor, la verdad y el bien, Salamanca 2006 (especialmente el capítulo Breve teoría de la verdad), del destacado filósofo chileno L. Razeto, En búsqueda del ser y de la verdad perdidos, Santiago 2004, y del fenomenólogo canadiense J. Grondin, en especial su breve obra Del sentido de la vida. Un ensayo filosófico, Barcelona 2005.

(110) El dolor, 114 
profesa una dedicación a la verdad, tiene lugar habitualmente una actitud excluyente o dogmática que no se da -o al menos no es tan frecuente- en otros campos de la cultura. Paradójica es tal actitud tanto más cuanto que, en relación con la verdad misma, la filosofía preconiza por principio el ejercicio del pensamiento, que por el contrario aparece neutralizado en aquel supuesto. ¿Tiene acaso que ver esto con la propia noción de verdad, y muy expresamente con la noción de verdad como correspondencia? Sin duda, no con lo primero, pero probablemente sí con una forma de entender lo segundo. Nos imaginamos, por ejemplo, que la famosa fórmula de Einstein, si es verdadera, lo ha tenido que ser siempre y lo será siempre también. Puesto que siempre ha habido energía, siempre habrá sido verdad $E=m c^{2}$. Pero la verdad de la energía no ha existido antes de que fuera formulada. Antes existía la energía, pero no su verdad. La verdad acontece (Heidegger habla aquí de geschehen, de ereignet y también de una Wahrheit-Geschehen), como se ha dicho con razón, sacando por lo demás consecuencias de una noción de verdad muy antigua (111). Sin embargo en la filosofía misma ha sido hipostasiada, convertida en noción, en lugar de dejar curso libre a su manifestación (así la verdad según Heidegger no es an sich vorhanden, no es Zeitloses und Überzeitliches). Al hipostasiarla se le ha sometido a medida, en lugar de reconocer que solo ella es la medida, de sí misma y de su contrario, lo falso. A ese fenómeno de la hipostasiación ha contribuido el hecho de haber interpretado uno de los términos de la adaequatio, el intellectus, como noción o concepto en el sentido de expresar la idea que posee la mente acerca de algo determinado, idea con la que la cosa en cuestión concuerda o que ella misma concuerda o se hace concordar con aquella, pero que en todo caso está ya, como tal, establecida (112). El intellectus en cambio es la palabra, el verbum mentis, que no expresa una idea previamente establecida, sino el proceso que va de una noción forzosamente abstracta a una noción concreta, resultado de todo aquel proceso. Por ejemplo, ante mí tengo el hermoso cuadro sobre Cristo de Fernando Prats que está en nuestra Sala de Consejo, un cuadro que veo por primera vez. Me doy cuenta en seguida que es un cuadro y puedo afirmarlo "en verdad" sin miedo a equivocarme. Pero esto es una verdad abstracta, aquella en lo que coincide con cualquier otro cuadro. La verdad del cuadro es muy otra: exige conocer la fuente de inspiración, la intención, el desarrollo, el proceso de la plasmación en la tela, etc., es decir, forma y contenidos determinados del cuadro en cuestión. Y para ello es preciso dejar y hacer que el cuadro se nos manifieste, es ineludible dejarlo manifestarse en su propia textura, en su "constitución de sentido" (el sinnhaft de Husserl). Toda cosa tiene, en efecto, algo que "comunicar" desde sí misma. Solo por ello es posible decir sobre

(111) Aquí nos remitimos sobre todo a De la esencia de la verdad en: id., Hitos, Madrid 2001, 151-172, que resume bien el sentido del uso del término antiguo de ả $\lambda \hat{\theta} \in \iota \alpha$-que significa una auténtica subversión ontológica frente a los corsés que la lógica decimonónica, el positivismo y el neokantismo le habían impuesto a la idea de verdad, sobre todo desde la perspectiva que la verdad sea una dimensión que está cerrada de antemano, con lo que se abren dimensiones ignoradas de la realidad-, donde es muy importante el uso análogo del prefijo a griego y los prefijos alemanes que dan la idea de des-ocultar (por ejemplo Entbergen). Además la verdad significa revelaciónrevelar-carácter de revelado (Offenbarung, sich offenbaren, Offenbarkeit) y es lo que abre en-elmundo al "misterio" (Geheimnis).

(112) Cf. Id., De la doctrina platónica de la verdad, en: Hitos, 173-198. 
ella algo con sentido. Pero entonces la idea que inicialmente teníamos de cuadro, o incluso de este cuadro, habrá tenido que confrontarse una y otra vez con los contenidos que la cosa ha ido desvelando de sí misma. La noción de cosa a que se llega es así fruto de un proceso lingüístico, y como tal modificable, puesto que se ha llegado como consecuencia de abordar la elaboración del concepto desde una perspectiva concreta y siguiendo un camino determinado. El concepto se sabe por ello deudor de aquella perspectiva y de este camino. La diferencia entre considerar la palabra o considerar el concepto -en cuanto noción definitivamente fijada- como lo que corresponde a la cosa está, por tanto, en que en el primer caso se anula el carácter dogmático, que es un principio inherente al concepto en cuanto que a este se le ve como medida establecida a la cual ya de antemano haya de ajustarse la cosa.

La cuestión se concreta, después de lo que hemos visto, en lo siguiente: dando por supuesto que Jesús es el Cristo, el enviado de Dios, Hijo de Dios, de la misma naturaleza que el Padre, cuya presencia epiclética (Zizioulas) se perpetúa en la Iglesia, se pregunta por el concepto de verdad que de razón de esos enunciados, en el sentido de que, admitiendo que son verdaderos, implican justamente un determinado concepto de verdad, que no puede ser el mismo que si tales enunciados no fueran verdaderos.

Peter Hünermann ha realizado con respecto a lo que venimos diciendo un aporte muy significativo, en especial sobre una temática muy relevante para nosotros, como la búsqueda de una mediación para poder hablar en teología de sucesos contingentes que portan exigencias universales (113). A modo de tesis, este teólogo afirma que la experiencia de la verdad y de la salvación por Jesucristo suscita la pregunta por el fundamental carácter de revelación y redención del encuentro más allá de la definición corriente de verdad como adaequatio intellectus et rei, y de la libertad como dominium sui, con lo que se abre la perspectiva de la comprensión histórica del encuentro con Jesucristo como una experiencia escatológica de revelación y salvación. El problema que se plantea, y que es el que nos convoca en estas páginas, es que dado que en Jesucristo se trata de un hecho contingente, y dado que las consideraciones sobre el acontecimiento de la realidad tienen un carácter muy estructural y de principio, se plantea el problema de la "mediación" de ambos momentos. Retomando la tesis recién señalada, este autor nos indica que lo que los evangelios nos transmiten no son en realidad otra cosa que "encuentros" frente a los cuales los hombres se abren y se transforman en el encuentro con Jesucristo. En el encuentro, en la acogida brindada, se apropia el hombre de la verdad y la salvación. Señala Hünermann que los muchos testimonios de encuentro de la Escritura nos remiten a la pregunta por el carácter fundamental de encuentro entre los hombres, interrogante que se plantea de manera todavía más urgente, si tenemos en consideración que este término -clave para la Teología fundamental a partir de la Dei Verbum-, está lejos de ser frecuente en la tradición filosófica (aquí Hünermann se remite a lo que han reflexionado, entre otros, Casper y Levinas, quienes hablan de aquel plano del encuentro en el que acontece verdaderamente algo, en el que se

(113) Cf. Cristología, 415-474; id., Fe, tradición y teología como acontecer de habla y verdad. Dogmática fundamental, Barcelona 2006, 30ss. 
produce un cambio, una transformación en los afectados por el encuentro (114)). Y cobra aún mayor premura si se considera que, por un lado, la filosofía ha definido desde antiguo la verdad como adaequatio intellectus et rei y, por otra parte, a la libertad como dominium sui. Así, pues, si el encuentro con Jesús supone revelación, es decir, "descubrimiento" (Aufdeckung) de la verdad de hombre y Dios, y transmisión de salvación, la que, evidentemente, se encuentra relacionada con la realización cumplida y feliz de la libertad, la cuestión será qué hay en el encuentro para que sea precisamente él quien sirva de "mediador" (Vermittlung) en dicha transmisión, con lo que Hünermann se pregunta: “¿No está el encuentro, en efecto, indisolublemente ligado a lo episódico, a lo anecdótico? ¿No es esta una categoría opuesta a toda reflexión filosófica?" (115) Argumenta este autor, que si se caracteriza esencialmente al hombre como quien está inmerso en el acontecimiento de la apertura, del ser, de lo sagrado, hay que notar, sin embrago, que en el trato inmediato con las cosas y los demás hombres, la apertura del acontecimiento del cual formamos parte no pocas veces es pasada por alto. Ese acontecimiento esencial se nos manifiesta, afirma Hünermann, ante todo en y por medio de otros encuentros que nos marcan y que hacen que de pronto empezamos a mirar la realidad con otros ojos, con lo que nos sentimos comprometidos de otra forma con la verdad, la justicia y la honradez; y aquí se interroga el teólogo de Tübingen: “¿en qué sentido podemos pensar que en el encuentro la realidad se abre en una forma nueva (daß sich in der Begegnung die Wirklichkeit in einer neuen Weise erschließt), y el auténtico ser-sí-mismo del hombre se manifiesta de un modo distinto?" (116) En el encuentro pueden suceder tales cosas, expresa Hünermann, porque el hombre que nos sale al encuentro se manifiesta esencialmente testigo de aquella medida de humanidad que prevalece en el acontecimiento de la apertura, del ser, de lo sagrado. Se trata de aquella medida inefable del ser del hombre que es a la vez nada y luz. Cada encuentro vive de ese oculto misterio que en modo alguno necesita ser analizado como tal y del que, sin embargo, da testimonio el hombre que sale a nuestro encuentro. Así Hünermann señala, ayudándonos a profundizar lo que nosotros estamos desarrollando en nuestras reflexiones, que verdad y promesa de sentido se manifiesta aquí de una forma mucho más profunda de la que se da en la fórmula de la adaecuatio, pues en esta se pasa por alto que aquello de lo que verdaderamente se trata, la "cosa" (Sache) misma, puede significar cosas muy distintas, de modo que el acceso a ella puede revestir también muy diversas formas. Si de lo que se trata es la verdad y el sentido de las dimensiones más profundas del hombre, el mundo, el ser, etc., las cosas no son tan obvias. Todo ello nos sale al encuentro en los otros hombres, en testigos, donde se nos revela, comparece la verdad. Este testigo llama a los hombres a salir fuera de sus muchas ideas (una auténtica $\mu \in T \alpha ́ v o \iota \alpha$ ) y caminar hacia su propia mismidad, lo cual implica salir en dirección hacia aquella frontera en la que se convierte en vecino de la nada, la cual, con todo, no se le impone como vacía nada. En este encuentro el hombre aprende a ver el mundo, la vida, con otros ojos, y en este sentido el encuen-

(114) Nosotros junto con García-Baró añadiríamos que la verdad no es conocimiento sino diálogo.

(115) Cristología, 445.

(116) Ibíd. 
tro tiene un carácter liberador-salvífico. En el encuentro alguien me encuentra como testigo del acontecimiento del que el hombre forma parte. Ahora bien, el encuentro, apunta Hünermann, puede acontecer de dos formas distintas. Alguien puede encontrarme, en la primera forma, como testigo del acontecimiento de lo sagrado. Lo que él es, la manera en que se da y me sale al encuentro, dan testimonio de su personal entrega en dicho misterio. Son testimonio de una realización existencial, en la que él mismo se ha incardinado dentro de ese misterio insondable. En él hay un espíritu que me toca, despertando en mí idéntico espíritu. Este crece y se manifiesta en la manera en que aquel que me sale al encuentro se mantiene libre en sí y en el acontecimiento de la apertura, de lo sagrado, sabe soportar finitud de la vida y, pese a lo imprevisible e inseguro de su existencia, es capaz de caminar con fortaleza. El espíritu se alimenta de la comprensión y confianza ocultas del hombre en aquel poder que no solo le afecta en el acontecimiento de la apertura del ser y de lo sagrado, sino que le alcanza, sostiene y guarda. Se produce la otra forma del encuentro, agrega nuestro autor, allí donde quien sale al paso no se ha entregado al acontecimiento de lo sagrado. Un planteo como el de Levinas demuestra cómo allí, en el "Otro", me está llegando una llamada incondicional que me compromete. También aquí despierta el espíritu porque, en el encuentro con otro el hombre es llamado a sí mismo al ser reclamado por otro. El hombre no se posee originariamente. Así, a la libertad, su auténtica realización solo se la suministran los encuentros, con lo que a aquella, como dominium sui, pertenecen también la benevolencia y el espíritu, la promesa y la exigencia, las cuales alcanzan al hombre en el encuentro. Cuando el encuentro comunica espíritu, cuando el hombre hace frente al otro como testigo del acontecimiento de lo sagrado, tiene lugar un confiarse-al-otro, una fe que en la figura de la humanidad-con-otros se define como "trascendental". Así, al señalar las características del envío de Jesucristo, nos recuerda Hünermann que el núcleo de aquellas radica en que Cristo sale al encuentro del hombre con potestad, ungido por el Espíritu. Los evangelistas presentan a Jesús como testigo de Dios (117), como aquel que es guiado en todo momento por el Espíritu y es colmado por él. Los acontecimientos pascuales están descritos como aquellos encuentros en los que el Señor se revela como aquel a quien ha sido conferido todo poder y otorga la plenitud del Espíritu. Los acontecimientos pascuales se convierten así en encuentro de plenitud escatológica.

Al terminar este punto queremos retomar la idea de que aceptar como verdaderos los enunciados cristológicos ya señalados, no significa que el concepto de verdad sea algo superpuesto o simplemente extraído de la mera facticidad de los enunciados. Porque si estos son verdaderos, lo serán en virtud de la verdad misma. Y en consecuencia, decir que si se admite que Jesús es el Hijo de Dios, etc., de ahí se desprende un determinado concepto de verdad, equivale a afirmar que el concepto mismo de verdad lleva en sí el hecho fundacional del cristianismo y su despliegue, dotado de un carácter específico, completamente diferente del que corresponde a cualquier otro

(117) "Creo en testigos que se dejan degollar" nos recordaba Pascal. Para profundizar la relación verdad-testimonio, sobre todo en la perspectiva de la resurrección, cf. C. Geffré, El cristianismo ante el riesgo, 109-127.224ss 
acontecimiento (118). Pues una cosa es que el hecho y su significado fundamental solo nos sean conocidos por revelación y otra, muy diferente, que el concepto de verdad ha de poder dar razón de ese hecho fundamental, de manera que sea composible con cualquier otro hecho o acontecimiento. Como bien señala W. Kasper: "Aparece con claridad el significado antropológico del oficio profético de Jesucristo cuando se piensa que la pregunta acerca de la verdad es un interrogante primordial del hombre y que la luz es uno de los símbolos más antiguos de la humanidad. Verdad y luz no son algo complementario que se añade a la realidad del hombre; son el único medium en el que la vida humana es posible. Solo donde hay luz y donde la cosa se manifiesta de forma totalmente patente $(=\alpha \dot{a}-\lambda \eta \dot{\theta} \theta \in \iota \alpha)$ puede orientarse y situarse el hombre en el mundo. La luz es, pues, símbolo de la salvación, mientras que la oscuridad simboliza la perdición... el oscurecimiento es consecuencia del pecado y signo de que el hombre no se encuentra en una situación de salvación. Por consiguiente, cuando se proclama a Jesucristo... como la luz, se pretende manifestar que él ha descubierto al hombre la verdad sobre sí mismo y sobre su mundo, en medio de las múltiples luces engañosas y cegadoras del mundo" (119).

Cristo como exigencia de verdad no significará por tanto que nos lo acomodamos a un concepto de verdad previo, sino que el propio concepto de verdad se "amplía" (disclousing) y se modifica esencialmente, iluminado desde dentro por aquel hecho (120). En referencia a lo dicho anteriormente sobre Schelling, son especialmente pertinentes las siguientes palabras de Kasper sobre este filósofo alemán: "El método de una mediación histórica del cristianismo no puede significar ya que el acontecimiento de Cristo es absorbido en la idea absoluta, o que ha de ser encuadrado en un apriori de un determinado sistema histórico-filosófico. Por eso, el acontecimiento de Cristo solo puede ser hecho comprensible a posteriori, a partir de sus premisas propias. Hay que estar dispuesto a ampliar las categorías que lleva consigo, para comprender este suceso. La historia no es solo una forma de aparición o representación de la verdad. La verdad acontece, más bien, como historia. Allí donde la historia en general y el suceso de Cristo en particular son entendidos como el suceso del futuro absoluto de Dios, solo allí es posible todavía un sistema abierto históricamente, un sistema que puede probar su verdad plenamente al fin de la historia y, por tanto, que solo puede ser verificado de modo escatológico" (121). Esto supuesto, son dos los aspectos fundamentales, diferentes entre sí y que, al mismo tiempo, se conjuntan formando una unidad indisoluble: 2) lo estricta e irre-

(118) Cf. J. Ladrière, La perspective eschatologique en philosophie, en: Temps et eschatologie, Paris 1994, quien dice: "De tal forma que sería necesario afirmar que el misterio cristiano es la verdad misma de nuestro mundo" (191).

(119) Cristología y antropología, en: id., Teología e Iglesia, Barcelona 1989, 285-286. Y más adelante agrega el autor: "Jesucristo es la verdad sobre el hombre. En él vuelve a brillar con todo resplandor la verdad y la luz que brilla desde el principio del mundo, pero que fue reprimida... Él redescubre al hombre su condición de criatura e interpreta así la existencia del hombre como existencia inmerecida que encuentra su sentido no en los méritos propios, sino en la acción de gracias (im Danken). Él revela (offenbart) e interpreta (deutet) al hombre el enigma de su realidad, al que de suyo podría acceder con su propia razón... El evangelio de Jesucristo interpreta los “signos de los tiempos'; es una interpretación profética de la realidad" (286-287).

(120) Cf. R. Schaeffler, Philosopische Einübung in die Theologie, vols. I-III, Freiburg 2004.

(121) Crisis y nuevo planteamiento, 200-201. 
ductiblemente fáctico, el acontecimiento por antonomasia de la encarnación; 3) el sentido que con él adquiere el hombre, cada vida humana.

\section{Lo estricta e irreductiblemente fáctico: el acontecimiento por antonomasia de la encarnación}

Tendemos a representarnos la encarnación de tal forma que quede a salvo la absoluta perfección de Dios desde toda la eternidad, perfección a la que la encarnación del Verbo en el tiempo no añade ni quita nada, encarnación que a su vez es conveniente para subvenir a la imperfección, a la miseria humana en palabras de san Agustín. Pero, por otra parte, al pensamiento le urge la pregunta: ¿qué tiene de realmente $-\mathrm{y}$ no solo metafóricamente- divino un acontecimiento que es temporal e histórico y que, por tanto, se sitúa fuera del círculo de un Dios inmutable que eternamente se basta a sí mismo y que no admite ni puede admitir dentro de sí nada que no sea él mismo? ¿Podemos acaso afirmar como propios y esenciales de Dios los rasgos del ser de Parménides (si se explica a Dios con relación a la categoría de "ser" inaugurada por este pensador griego, aquel queda interpretado al interior de una inmutabilidad fría y rígida: "no engendrado, es también impere-

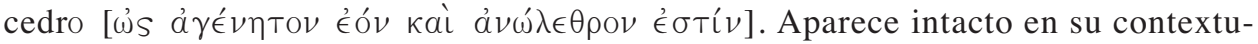

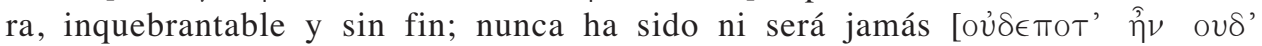

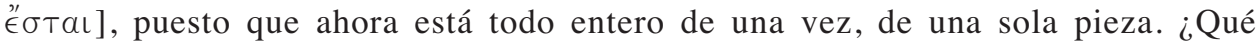

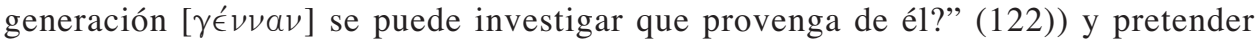
hacerlos compatibles con formas de actuación -nacimiento de mujer, en un lugar y un tiempo determinados, dentro de los condicionamientos de la más precaria y estricta finitud- que son ajenas a aquel concepto? (123) ¿Qué inconveniente hay, por el contrario, en representarnos las cosas de otro modo, más o menos del siguiente: Dios, absolutamente perfecto e inmutable sin duda, decide mediante una acción idéntica con su ser, coherente con su naturaleza y en tal sentido no menos necesaria y libre que él mismo, encarnarse, devenir hombre, nacer y morir en un tiempo determinado, de modo que este término de su acción es él mismo, expresión y culminación de su propio ser? La representación se resiste en buena lógica a aceptar esto, porque parece implicar que Dios adquiere en un momento dado algo que antes no poseía. A lo cual es fácil contestar diciendo que en Dios no hay antes ni después. Pero no menos fácil y contundente será la réplica, consistente en decir que en tal caso Dios no se encarna realmente -dado que la encarnación implica asunción de la temporalidad-, con lo cual de nuevo nos veríamos inmersos en el círculo que pretendíamos eludir.

En este punto nos vemos incitados a modificar el concepto ontológico fundamental de verdad, que en lugar de significar la presencia eterna de la realidad inmutable a

(122) Die Fragmente der Vorsokratiker, vol. I, W. Kranz (ed.), Berlin 1972, 235.

(123) Esta pregunta, clave en la lógica de nuestras reflexiones, se agudizó aún más luego de la profunda ponencia de M. Enders y la posterior discusión al inicio de este Seminario. En la ponencia de Sergio Silva se recoge esta disputa y se señala que una filosofía de la "no relacionalidad" es prácticamente incompatible con la búsqueda de pistas de solución a la pregunta que nos convoca en este Seminario, pues, entre otras consecuencias, dificulta pensar en toda su verdad la encarnación (cf. Lo absoluto y lo relativo. Aproximación hermenéutica, 8-9). 


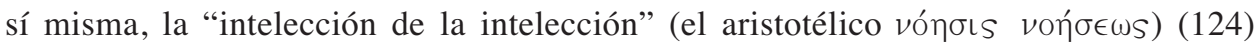
tendrá que entenderse como desocultamiento, como un hacerse presente a sí misma en este hombre concreto, como un constituirse en plenitud en el tiempo y en la historia (125). Nada habría que oponer, puesto que en nada se vería menoscabada la absoluta perfección, si el concepto de esta postula ese tipo de manifestación a sí misma. ¿Por qué va a ser perfecto un ser que descansa en sí y se basta plenamente a sí mismo y luego decide gratuitamente $-\mathrm{y}$ sin que a ello se vea necesitado en modo algunocomunicarse a los hombres, y no va a ser perfecto más bien un ser que se caracteriza por ser constitutivamente esa "comunicación" (Sergio Silva)? Con su habitual agudeza, Ricoeur se refiere a un Dios excesivamente interpretado en clave teísta: "[se trata] de una divinidad más eminente que vigilante, bienaventurada como el espacio, pero no patética como el Dios de Israel, implicado en la historia de la Alianza" (126), y más adelante continúa reflexionando sobre la diferencia "entre un Dios 'patético' que

(124) Como bien señala Gesché: "Ese Dios del cosmos, por otra parte, cuya esencia consiste en ocuparse de sí mismo (él es pensamiento de sí mismo, producto de su propio pensar, noesis noesos), ese no es el Dios del hombre. Para decirlo en términos actuales, invirtiendo la famosa frase de Grotius (etsi Deus non daretur), la teología de Aristóteles es la de un Deus etsi homo non daretur. El tratado pseudo-aristotélico De mundo, cuya importancia en la teología medieval es bien conocida, considera a Dios esencialmente como un poder cósmico" [...] "Para Aristóteles... Dios es en última instancia su propio teólogo, noesis noesos, pensamiento del pensamiento, teólogo del Pensamiento que es él mismo. Desde la Encarnación el hombre se ha convertido en teólogo de Dios... hemos dejado claro que toda inmanencia posee su trascendencia y se comprende en ella, y que toda trascendencia posee su inmanencia y se comprende en ella. Aquí queda expresada toda la cristología como antropología" (Jesucristo, 34.57).

(125) Desde una perspectiva bíblica nótese el título ("La verdad se deja encontrar") de la siguiente obra de J. Zink, Die Wahrheit läßt sich finden, Stuttgat 1971, donde resulta muy importante la metáfora del "camino" y del "seguimiento" de Cristo en relación a la verdad cristiana.

(126) Lectures, vol. 3, 180. Le debemos mucho en este ámbito a las reflexiones que nuestro colega Samuel Fernández ha llevado a cabo sobre la pasibilidad de Dios en Orígenes (cf. "Passio caritatis" according to Origen in Ezechielm Homiliae VI in the ligth of Dt 1, 31, Vigiliae Christianae 60 [2006], 135-147). Comentando el versículo de Ez 16, 5, "para que yo pudiera sufrir algo compadecido de ti", este Padre descubre de improviso un Dios capaz de padecer. Anunciado por Ezequiel, él lo descubre en Jesucristo: “[El Salvador] descendió sobre la tierra apiadándose (miserans) del género humano, experimentó pacientemente nuestras pasiones, y todo ello mucho antes de someterse al suplicio de la cruz y de dignarse tomar nuestra carne" (Hom. Ez., VI 6 [SC $352,228-231])$. Es de gran importancia que Orígenes no limite la pasibilidad de Cristo a los padecimientos de la cruz, sino a sufrimientos anteriores a la pasión e incluso anterior a la encarnación. Pasibilidad por tanto, que afecta al Salvador, no por simple voluntad exterior, sino por su misma condición divina. Y agrega este Padre Griego: "Porque si él no hubiera sufrido [anteriormente], tampoco hubiera venido a compartir la vida humana". No se trata únicamente de que él haya compartido nuestros sufrimientos por haber descendido; más bien, él ha descendido porque previamente había compartido nuestra situación de sufrimiento. Ciertamente se trata de una pasión ( $\pi \alpha / \theta 0 \varphi$, passio), algo que los griegos consideraban estaño e inadmisible en Dios; eso es lo que el Verbo (no "simplemente" el Cristo hombre) experimentó y sufrió. Orígenes va aquí aún más lejos, al referir la passio al Padre: ¿"No padece también él en cierto sentido? ¿No sabes tú... que cuando se ocupa de los asuntos humanos también él experimenta una pasión humana? Evocando Dt 1, 31 concluye este autor osadamente: "Dios toma pues, sobre sí nuestra manera de ser... el Padre no es impasible". Así el hombre es el amor de Dios; la $\phi \iota \lambda \alpha \nu \theta \rho \omega \pi \mathrm{\imath} / \alpha$ es el amor que él posee como algo propio. Dios, dice este gran teólogo, experimentando de este modo pasión por el hombre, "asumió un modo de ser incompatible con la grandeza de su naturaleza". Así, tenemos que vérnoslas con una epistemología completamente distinta y con una "ontología" de Dios que nada tiene que ver con la que se repite en los discursos referentes a la impasibilidad. Quizá haya que subrayar con más insistencia que una condición de posibilidad trascendental -en 
busca al hombre, y la noción griega de un 'divino' (theion) el cual, más que una persona, es un Principio, un Fundamento, un Orden" (127).

Y si es comunicación, ¿qué es a su vez más perfecto, que tal comunicación se dé de igual a igual, entre personas que son una el reflejo de la otra y por ello se funden entre sí en una misma y única naturaleza, o que esa comunicación se haga última y definitivamente real, no en lo que es infinito, sino en lo que es infinitamente más pobre, desvalido y necesitado (el "verdadero infinito” de Hegel)? ¿La gloria de Dios habrá de consistir en una majestad que se recrea en sí misma o en deleitarse con la compañía de los hijos de los hombres? Lo que con ello se sugiere es que la encarnación no es algo que acontece porque Dios lo ha querido pudiendo no haberlo querido, sino que es un acontecimiento en que culmina el ser mismo de Dios, en que lo más alto se funde con lo más bajo, lo más fuerte con lo más débil, lo más profundo y originario con lo que en apariencia es accidental o meramente contingente (128). J. Ratzinger ha insistido sobre esto en su obra Introducción al cristianismo y recientemente como Benedicto XVI en su encíclica Deus caritas est. Así, en aquella obra programática como profesor tubingués nos señala, precisamente cuando se dedica a precisar cuál es la esencia del cristianismo, que en el epitafio de San Ignacio de Loyola se encuentra un dicho anónimo que bien puede considerarse un precipitado de la imagen cristiana de la verdadera grandeza de Dios: es divino no estar encerrado en lo máximo y estar, sin embargo, contenido en lo mínimo (129). El espíritu ilimitado que contiene en sí la totalidad del ser supera lo "más grande" porque para él es pequeño, pero llega también a lo más pequeño porque para él nada es demasiado pequeño. Esta superación de lo más grande y esta entrada en lo más pequeño constituye la verdadera esencia de Dios. Pero, simultáneamente, como le gusta subrayar al Papa actual, se manifiesta aquí una valoración del maximum y de lo minimum, que es muy importante para la interpretación cristiana de lo real-creado. Para quien, como espíritu, lleva y transforma el universo, un espíritu, el corazón de un hombre que puede amar, como la huella del creador en él, como su profecía de felicidad y acabamiento, es mucho mayor que todo el universo y sus millones de galaxias. Las medidas cuantitativas quedan así superadas, con lo que aquí se señala otra jerarquía, otro ordo de grandeza, en la que lo pequeño pero ilimitado es lo verdaderamente incomprensible y grande. Con lo anterior cae un prejuicio muy extendido: nos parece evidente que lo grande ilimitado, el espíritu absoluto, no puede ser sentimiento ni pasión, sino solamente pura matemática de todo. Sin darnos cuenta afirmamos de esta forma que el puro pensar es mayor que el amor, mientras

el doble sentido de la expresión- de todo el andamiaje que sostiene la pegunta que nos convoca en este Seminario, y que permite pensar lo absoluto y lo contingente en "unidad y diferencia" está, en la línea del exegeta Orígenes, en la afirmación de Schelling: "Dieu est fou de 1’homme" (Darstellung des philosophischen Empirismus, en: Werke [ed. K. F. A. Schelling], vol. X, Stuttgart 1856-1861, 273). En una iluminadora reflexión, A. Gesché también ha abierto un camino a través de esta idea de la "locura" vinculada al Dios-amor, y ha relacionado esto con el nuevo estatuto que adquiere el pobre y el marginado en el cristianismo. Con esto el cristianismo ha revelado la verdad del mundo y la creación (Jesucristo, 46-48). Ver también S. Breton, Le Verbe et la Croix, Paris 1981.

(127) Lectures, vol. 3, 184.

(128) Cf. J. Ratzinger, Introducción al cristianismo, Salamanca 1971, 117-119.

(129) "Non coerceri maximo, contineri tamen a minimo, divinum est". 
que el mensaje del evangelio (Jesucristo como el evangelio de Dios) y de la imagen cristiana de Dios purifican siempre la idea de Dios hecha a nuestra medida y nos hacen ver que el amor es superior al puro pensar. El pensar absoluto es un amor, no una idea insensible, sino creadora, porque es amor (130).

Así pues es necesario enfrentarse a una pregunta clave que nos tenemos que hacer los teólogos de cara a la problemática que nos convoca en este Seminario y que siempre ha salido a colación: ¿dónde se sitúa, pues, y dónde se demuestra la verdadera divinidad de Dios? La trascendencia de Dios no es la que nosotros creemos; se trata de una trascendencia que no tiene miedo de nuestra inmanencia (131). Levinas apunta que ahí está toda la diferencia entre la trascendencia filosófica o teísta y la trascendencia cristiana o teológica: "La idea de una verdad cuya manifestación no es gloriosa ni deslumbrante, la idea de una verdad que se manifiesta en su humildad, como la voz de un fino silencio -según la expresión bíblica-, ¿no es esa la única modalidad posible de la trascendencia? No a causa de la cualidad moral de la humildad (que yo no quiero, por otra parte, criticar en absoluto), sino a causa de su manera de ser, donde está quizás la fuente de su valor moral. La humildad y la pobreza son una manera de estar presente en el ser -un modo ontológico-" (132). Si M. Merleau-Ponty tenía miedo que el hombre pudiera morir al contacto con el Absoluto, nosotros sabemos, precisamente como cristianos, que Dios no muere al entrar en contacto con lo relativo.

La grandeza no se conquista al precio de una despiadada separación (133). Sucede que quizá hablamos de Dios en términos dignos probablemente en su intención (omnipotencia, por ejemplo), pero el uso que hacemos termina por hacerlos sospechosos de una violencia que puede convertirlos en endebles (134). Aquí está el peligro del $\dot{u} \pi \epsilon \rho \delta \xi \hat{\xi} \zeta \epsilon \iota \nu$ del que hablaba Orígenes (135), lo cual convoca a una verdadera superstición (superstitio $=$ aumentar) y convocan no pocos ateísmos, como aquel paradigmático de Epicureo, que frente al dios "impasible y bienaventurado" se declaraba ateo (136). Como ocurre frecuentemente, lo que enfatiza con exceso,

(130) Cf. Benedicto XVI, Deus caritas est, n. 9-12.

(131) A propósito de la etimología de la idea de trascendencia señala Gesché: “...'transcendens' (participio activo): no solamente aquel que es trascendente por sí mismo y para sí mismo..., sino aquel que hace trascender, es decir, el transcendante (trascendedor), aquel que me eleva, que me hace 'trans-gredir'..., desde el estado en que yo me encuentro, para ir más allá. Pero precisamente por esto es necesario que sea efectivamente más grande, que sea Trascendente (y eventualmente el Trascendente), para hacer posible este 'sobrepasamiento"' (Dios para pensar, vol. VII, El sentido, 73).

(132) Entre nous. Essai sur le penser-à-l'autre, Paris 1991, 71. Ver también las valiosas pistas que entrega G. Vattimo en Espérer croire, Paris 1998, 59.

(133) Cf. G. Vattimo, Espérer croie. Aquí hay que aprender mucho del sentido de la palabra "santo" como "propiedad" divina en el Antiguo Testamento, en especial en el profeta Oseas (y a la vez relacionar la "teología" de este profeta con la idea de locura antes expresada por nosotros).

(134) Cf. A. Gesché-P. Scolas (eds.), Dieu à l'epreve de notre cri, Paris 1990.

(135) In Jn., XIII, 25, 151 (SC 222, 114). Y más recientemente Gesché nos recuerda que "al encarnarse, el Verbo no transgrede su trascendencia" (Jesucristo, 262).

(136) Recordemos la señera pregunta de Blondel: “... todo el debate de la filosofía y de la vida se retrotrae a esta opción: el secreto del ser, la palabra del enigma, ¿es acaso una verdad impersonal e impasible, o es una intimidad, una ternura, una caridad?" (Léon Ollé-Laprune [1839-1898], Paris s.f., 44); o la más reciente de García-Baró “¿y si primordialmente la verdad no fuera sentido inerte, sino algo así como amor?” (Del dolor, 126). 
como nos recordaba Vicente Huidobro a propósito de los adjetivos, traiciona la verdadera grandeza. Como bien diagnosticaba Ireneo "Los gnósticos creen haber descubierto por encima de Dios [del Dios de nuestra revelación] 'otro Dios', otra 'Plenitud'. Pero de este modo han deshonrado y despreciado a Dios al considerarlo 'muy inferior' porque, en su amor y en su bondad sin medida (immensam benignitatem), él vino para darse a conocer a los hombres" (137).

\section{El sentido que con Cristo adquiere el hombre, cada vida humana}

La encarnación, el devenir pleno de Dios, acontece en este hombre, Jesucristo, un individuo perfectamente determinado, enmarcado en las coordenadas de espacio y tiempo, condicionado por su lengua, su tierra, su pueblo y las contradicciones de su época. Este individuo, esta persona concreta es Dios, plenamente Dios y plenamente hombre. Con lo cual, para el concepto de verdad se desprenden las consideraciones siguientes. El individuo humano ya no es algo que en el conjunto de lo que existe es accidental en mayor o menor medida. A contracorriente de entonces, de ahora y de siempre, el individuo deja ver, a quien verdaderamente lo quiera mirar, la faz, el "rostro" (Meis) de una verdad absoluta dotada de los rasgos que aquí y ahora le son propios, ocultos sin duda en su mera presencia empírica, pero desocultables y así patentes, para quien quiera verlos. El individuo, en contra de cualquier actitud simplemente positiva, no es un mero dato, que pasa a formar parte de la objetivación, de la comparación y del cálculo. No es el resultado del azar, sino que lleva en sí el sello profundo de lo absoluto y es, cabe decir, fundamento de sí mismo. No es parte de un "sistema", sino que es un unicum.

Este individuo es finito, pero es irreductible, no es canjeable o sustituible. No es "clonable". Serán sustituibles sus funciones, sus aportaciones o incluso aquellas cosas que le hacen noble y distinguido ante los demás. No, en cambio, lo que es su ser propio en su desnudez, en ese ser-este y no otro (138). También esta verdad está -suele estar- oculta, es locura para los sabios, pero es verdad, es nuestra verdad.

$\mathrm{Y}$ en tercer lugar, este individuo que es Jesús de Nazaret y que es Dios no es un caso más del contenido de un concepto, participación de una idea o reflejo de un arquetipo. Es él el arquetipo ("caso irrepetiblemente supremo de la realización esencial de la realidad humana" (139)), lo cual trae consigo que los demás hombres se salvaguardan igualmente como individuos, que en lugar de dejarse reducir a un determinado concepto de humanidad, representan en su aquí y su ahora la única forma posible como aquella es y puede ser.

Lo que acabamos de decir encierra el peligro de la absolutización o de la divinización, de la tendencia del hombre a convertirse en centro en torno al cual se muevan y al que se supediten los demás. El sentido sin embargo es otro. Pues no

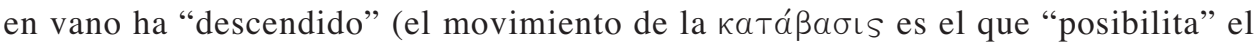

(137) Adversus haereses, III, 24 (SC 211, 477).

(138) Para esto nos atrevemos a remitir a nuestro artículo La vigencia de la pregunta teológica por el término "persona" para la imagen del hombre en la actualidad. El aporte de Hans Urs von Balthasar, Teología y Vida 42 (2001), 399-439.

(139) K. Rahner, Para una teología de la encarnación, en: id., Escritos de Teología, vol. IV, Madrid 1964,145 . 
responsorial de la áváßaఠıs) Dios y se ha despojado de su dignidad. La unidad de la naturaleza divina y de la naturaleza humana que la encarnación anuncia implica un proceso de clarificación, "sobrepujamiento" (140), transfiguración y acrisolamiento (141): "El Hijo de Dios se ha hecho hombre para que el hombre se haga Dios" (Atanasio); "Esta es la razón por la que el Verbo se hizo hombre: que el hombre, al recibir la filiación adoptiva, se convierta en Hijo de Dios" (Ireneo); "El Hijo único de Dios asumió nuestra naturaleza, a fin de que, hecho hombre, hiciera a los hombres Dios" (Santo Tomás). El hombre también deviene a través de un proceso pleno de privaciones, negaciones y contradicciones. Lo humano esencial no está dado inicialmente (Sein) sino como posibilidad que se actualiza (Seinkönnen, como señala Heidegger), se decanta y culmina en la forma en que se concreta el destino, que es llamada de Dios, pero que es también la forma como el hombre presencializa a Dios al apropiarse su envío o misión.

Los términos con que se expresa la unidad de Dios y hombre son entre otros, por lo que a Dios se refiere, los de condescendencia, filantropía, despojo, abajamiento a favor del hombre, que muy bien los sintetiza Clemente de Alejandría al señalar que "la pasión ( тò É $\mu \pi \alpha \theta \in$ És) de la cólera... es un acto filantrópico de Dios

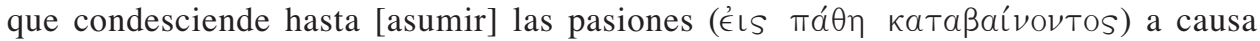
del hombre, por el cual el Logos de Dios se hizo hombre" (142), y por lo que se refiere al hombre, los de unificación, asunción o elevación en virtud del poder, la gracia y la benevolencia de Dios (143). Sea como fuere, el lenguaje se ve envuelto inevitablemente en imprecisiones, perplejidades y hasta contradicciones que nadie sabe percibir mejor que el teólogo dotado de sensibilidad. Pero al margen de esta inevitable limitación, encontramos aquí un doble peligro, al que pudiera no ser ajeno el mismo lenguaje: de una parte, acentuar tanto la presencia de lo divino que lo humano termina por perder consistencia y hasta legitimidad; de otra parte, ensalzar tanto la dignidad humana, o por mejor decir, ensalzarla de un modo tal que se termina cayendo en el endiosamiento - una inversión que sin duda es ya en sí misma una perversión que genera toda suerte de formas de idolatría- (144).

En este momento de nuestras reflexiones, resulta útil detenerse para recordar las equilibradas expresiones de Juan Damasceno en relación a la unión de la que venimos hablando a través del término $\pi \epsilon \rho \iota \chi \omega ́ \rho \eta \sigma \iota s$, y que tanta influencia ha tenido en la cristología actual (Hünermann, Schönborn entre otros). Juan Damasceno recibe de Máximo el Confesor este concepto de perichóresis y lo formula de la siguiente manera: "Unidos según la hipóstasis y poseyendo mutua perichóresis, se unen sin mezclarse" (145). Al mismo tiempo, profundiza este Padre esta idea utili-

(140) "Überbietung” como dice Kasper en Cristología y antropología, 282.

(141) Como agudamente anota A. Gesché: “... la encarnación se convierte en un verdadero 'concepto' para estudiar al hombre" (Jesucristo, 469).

(142) Pedagogus, I, 874, 4 (SC 70, 242).

(143) Cf. A. Gesché, Jesucristo, 253-254.

(144) Cf. las atinadas reflexiones de W. Kasper en Jesús el Cristo, Salamanca 2002, sobre todo la primera y tercera parte.

(145) Expositio fidei LII, en: Die Schriften des Johannes von Damaskus, vol. 2, (PTS vol. 12), Berlín 1973, 127; cf. J. P. Torrebiarte Aguilar, El Concepto de Perijoresis en la Expositio Fidei de San Juan Damasceno, Navarra 2003. 
zando el motivo de la relación de fundamentación propio de la tradición neoplatónica. De esta forma se le hace posible concebir la perichóresis no solo como resultado o efecto de la unión hipostática, sino también como un acontecimiento originario al momento de explicar el proceso de la unión hipostática. Así se desprende del hecho de

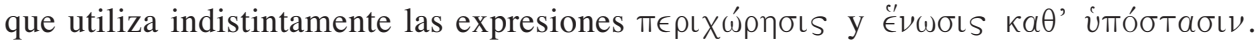
Además describe la perichóresis en términos de un proceso de fundamentación mutuo pero de desigual importancia: "La perichóresis no se hizo desde la carne, sino desde la divinidad. Pues es imposible que la carne penetre la divinidad, pero des-

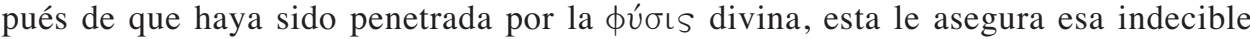
penetración que llamamos unión" (146). Así Juan Damasceno caracteriza la unión hipostática como un movimiento de doble dirección: descendente de revelación desde lo divino y ascendente de lo humano. Dentro del proceso, sin embargo, el movimiento de la revelación es el factor primario, fundacional, mientras que el movimiento ascensional humano es de carácter secundario, una respuesta a la iniciativa anterior. Sea como fuere, ambos movimientos tienen su destino en el otro. Así, el primer movimiento de la perichóresis parte de Dios, pero se hace visible en el hombre, siendo por ello llamado $\theta \in \hat{\imath} \omega \sigma \iota s$, divinización, y $\lambda o ́ \gamma \omega \sigma \iota s$, logificación, del ser humano. La existencia humana se ve arrastrada e introducida durante este proceso en la autonomía de Dios. A la inversa, el movimiento contrario parte del hombre, pero tiene su destino en Dios, razón por la que se le denomina con los nombres de

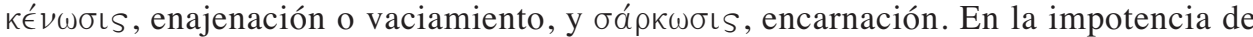
la carne se hace presente la Palabra misma de Dios: "Mediante la unión, en efecto, se pone de manifiesto lo que cada uno de ellos ha obtenido de la vinculación y perichóresis con el coexistente con él. Pues en razón de la unión hipostática se dice de la carne que se ha divinizado y hecho Dios y de la misma divinidad que el logos, y de Dios, del logos, se dice que se ha hecho carne y hombre y criatura, y se le denomina con este último nombre. Pero no porque ambas naturalezas se hubieran trasformado en una sola -es imposible, en efecto, que lo que por naturaleza se opone coexista en una naturaleza-, sino porque ambas naturalezas se han unido según la

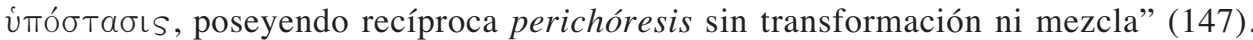
En referencia a los dos movimientos por los que se constituye la unión hipostática,

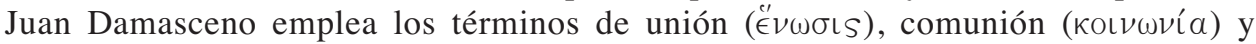
unción ( $\chi \rho\llcorner\sigma \hat{\mathrm{S}}$ ). La identidad o mismidad de Jesucristo, precisamente por estar constituida por los movimientos de revelación y ascensión, es en sí misma unión, comunión, unción. El contenido de su mismidad, son de nuevo la unión, la comunión, la unción. La cristología actual ha retomado la intuición del Damasceno y ha incorporado los acontecimientos de la vida de Jesús a ese proceso constitutivo del que hablaba este Padre. El verdadero sentido de la unión de Dios y hombre es así, expresado en relación con el concepto de verdad, que acontece la correspondencia de la realidad humana a la realidad divina o que el poder de Dios, al hacerse hombre, hace que la realidad de este aparezca, o si se quiere, en lenguaje de Heidegger se produzca un des-cubrimiento (Entborgenheit; también se habla aquí, en un

(146) Ibíd., LXI, 155; Ibíd., XCI, 214.

(147) Ibíd. 
juego de palabras de Ent-bergung) (148), y se haga valer en toda su integridad y radical desnudez, más allá o más acá de oropeles, vanidades o dignidades; al margen de localismos, peculiaridades étnicas o culturales; por encima de cuanto obstaculiza la visión o el reconocimiento del hombre como hombre.

Este hombre, que fue Jesús de Nazaret, es todos los hombres. Lo que aconteció una vez acontece ya siempre (149). La encarnación de Cristo implica que todo hombre, por el hecho de serlo y sin ninguna otra cualificación, es hijo de Dios. Tal vez lo más difícil de pensar sea la simultaneidad paradójica de la más estricta e irreductible singularidad y de la universalidad que no reconoce ningún tipo de limitación como no sea el hecho puro y simple de ser hombre. La encarnación de Cristo significa que Dios se ha hecho hombre y que, por tanto, allí donde hay un hombre -que no es ni puede ser nunca un hombre en general, abstracto, indeterminado- allí brilla la faz de Dios (150). Por eso, por la exigencia de la verdad, individualidad y universalidad son coincidentes en este caso; no se puede realzar más el reconocimiento de la realidad y de la dignidad humana. Como bien subraya Gesché en un claro contexto cristológico: "Proclamar este vínculo entre Dios y el hombre es darle a este el fundamento más absoluto y más definitivo para que pueda respetar y hacer que se respete su absoluta dignidad. Res sacra homo, el hombre es una cosa santa. Esa es la profecía divina" (151).

El planteo de M. Henry resulta aquí especialmente importante, y lo traigo a colación precisamente a propósito de lo dicho en el párrafo precedente, por su actualidad. Este fenomenólogo francés afirma que el descubrimiento cristiano de la filiación divina de Jesús no depende únicamente de una verdad teológica, sino, a su juicio, de una "verdad antropológica". Para Henry, la "verdad del cristianismo", es decir, lo que este ha aportado al mundo como propio, consiste en que ha hecho saber a los hombres que son hijos de Dios, lo cual constituye una verdadera hermenéutica, esto es, una semántica del hombre, cuya esencia es la Vida, esencia que él no encuentra más que en la filiación (ser hijo es recibir la vida y recibirse a sí mismo en ella). Decirle al hombre que es hijo de Dios es, por tanto, reconducirlo a sí mismo, a su verdadera "singularidad" y a su felicidad de ser. La desesperación que golpea a los hombres proviene del olvido que sufren de su condición de hijos, como ya lo había observado Plotino. En el fondo, junto al ordo creationis, que no es suficiente para dar cuenta del hombre, existe un ordo filiationis (152). ¿No se dará en este contexto antropológico, tal cual lo plantea Henry, un "ámbito de inserción" necesario para la proclamación del evangelio en la cultura actual que solicitaba J. Ladrière, sobre todo en relación a cómo afirmar que aquel Hijo es todos los hijos?

(148) Cf. De la esencia de la verdad, 151-171.

(149) Cf. K. Lehmann, Absolutheit, 35ss.

(150) Nuestra colega A. Meis ha tratado este tema desde la perspectiva de una teología del "rostro" (cf. Antropología Teológica, Santiago 22001, sobre todo 116-121).

(151) Jesucristo, 45. En este contexto sería útil estudiar detenidamente el diálogo sostenido hace poco por Ratzinger y Habermas,

(152) Cf. Yo soy la Verdad. Para una filosofía del cristianismo, Salamanca 2001; ver además J. Splett, Christologie-philosophisch, en: A. Batlogg et al (ed.), Was den Glauben in Bewegung bringt. Fundamentaltheologie in der Spur Jesu Christi, Freiburg 2004, 423-440. 
No es cierto el diagnóstico de que el cristianismo es platonismo (153). No lo es por un doble motivo: porque en rigor no tenemos que ver con la participación de una idea, por noble y elevada que esta sea, sino con la realización aquí y ahora de la idea absoluta y divina, de Dios mismo que se hizo hombre despojándose de su grandeza; y, por otra parte, tampoco es platonismo en cuanto que implique una desvirtuación o empobrecimiento de la realidad. No es así, porque al margen de desviaciones o malentendidos, la encarnación de Cristo implica, paralelamente al abajamiento de Dios, el desocultamiento de lo humano esencial (154).

Esto último es lo que en el fondo está detrás del epocal e inspirador texto de Gaudium et spes $\mathrm{n}^{\circ} 22$ citado al inicio de estas reflexiones. Toda la exposición de esta Constitución pastoral, y me atrevería a decir del Concilio, tiene su centro de gravedad en la afirmación que la persona de Cristo, como enviado del Padre, es un "hecho aclaratorio" (aufklärische Tat, como señala H.-J. Sander) de lo que es la verdad del hombre (vere clarescit), de sus temores y esperanzas. Esto tiene un significado para "cada" hombre (el Concilio habla que en la encarnación el Hijo "se ha unido, en cierto modo [quodammodo], con todo hombre"), por lo que de ahora en adelante no se podrá hablar de Dios sin hacerlo del hombre, y tampoco se podrá hablar de este sin la "aclaración" que obtiene en Cristo. Con ello, todo hombre está invitado a responder a las interrogantes que nacen del fondo de su búsqueda de sentido, en la praxis y palabras de Jesús. Esta "pequeña cristología" como la llama Sander, de talante pastoral, toca los temas del tratado en relación positiva a la salvación de los hombres. Así, la promoción de los valores del hombre (a la luz de una teología de la imagen y semejanza y de la ultima vocatio) son inseparables de la fe eclesial. Al concluir el comentario a este número, afirma Sander, en una frase que nos recuerda la larga discusión sobre la "pastoralidad de la teología", que a partir del nuevo "programa-marco" (Rahmenprogramm) que significa la afirmación que el quehacer teológico-pastoral de la Iglesia se nutre de la cristología, que la teología tiene una forma de saber "pastoral". Es decir, todo lo que hemos reflexionado en estas páginas quiere solo afirmar que el teólogo está al servicio de la Iglesia, a la labor pastoral de esta, que es en el fondo profetizar al verdadero hombre en Cristo (155). Como pertinazmente expresa J. Noemi lo recién dicho: “... la Iglesia es una realidad subordinada en su origen y en su fin. En su origen a la persona de Jesús

(153 Cf. C. E. Gunton, Unidad, Trinidad y pluralidad. Dios, la creación y la cultura de la modernidad, Salamanca 2005, 14.33.61-65.97.143ss.183ss; W. Pannenberg, La asimilación del concepto filosófico de Dios como problema dogmático de la antigua teología cristiana, en: id., Cuestiones, 93-149.

(154) Cf. W. Kasper, Cristología y antropología, 266-296; muy iluminadoras resultan las reflexiones de A. Gesché sobre la "cristología como antropología" en Jesucristo, 43-57. En este texto Gesché señala que la cristología es el "anuncio" de Dios y del hombre, es la "profecía” y "proclamación" de este. C. E. Gunton señala que lo cristológico implica, salvíficamente hablando, una "nueva manera de ser humano" (cf. Unidad 182ss).

(155) Cf. J. Splett, Im Dienst der Wahrheit. Abschiedsvorlesung, Theologie und Philosophie 80 (2005), 321-334. R. Schaeffler agrega que esta tarea -señalar a Cristo como la verdad del hombre, como quien abre a la experiencia definitiva de humanidad y mundo- se debe proponer por parte del teólogo al interior de la propia búsqueda de la filosofía que sistematiza las grandes preguntas del hombre (persona, naturaleza, libertad), y no solo como un discurso teológico externo (cf. Philosophische Einübung, vol. III, Philosophische Einübung in die Ekklesiologie und Christologie, 256ss). 
como el único y permanente unum subsistens que es la Verdad; y en su fin, al 'reino de Dios' como realidad definitiva de un único Dios que será 'todos en todos'. En la historia, la Iglesia y la teología no suplantan la verdad de Jesús ni del 'reino de Dios', sino que la actualizan y anticipan. En el presente la catolicidad solo puede acontecer como memoria del insuperable unum et verum subsistens, del universal concreto que es Jesucristo y como prolepsis del futuro 'todo en todos' de Dios. Esto la condiciona como necesariamente plural en el presente. La Iglesia no subsiste en la historia como católica por sí misma sino desde Jesús y hacia el Christus totus, que tampoco significa la supresión de la pluralidad sino plenificación de la misma como 'todo en todos"' (156).

Todas nuestras reflexiones teológico-filosóficas tienen así únicamente un carácter ancilar, pues deben servir para la labor eclesial de anunciar la "verdad" del hombre y el cosmos "en Cristo" (157). Un hombre para ser feliz, para realizarse, necesita alcanzar una "vida buena", una "vida lograda", lo que "sin metafísica no es posible” (D. Heinrich). Metafísica significa aquí, dicho con exceso de simpleza, por ejemplo, la convicción ya expresada por Platón en la República, que la vida humana es una "vida buena" cuando se conforma al modo en que las cosas son verdaderamente, cuando adquiere forma en el mundo tal como este es, es decir, una orientación hacia el bien dentro del cual podría desarrollarse la vida humana (158). Con ello afirmamos que el hombre busca un "foco trascendente" (Gunton) que le ofrezca coordenadas a nuestro ser y que por cierto durante largo tiempo fue Dios y hoy, en amplios espacios de la Modernidad, ha sido "reemplazado" por construcciones meramente humanas, lo cual ha traído complejas consecuencias al hombre y la creación. Así, hay que preguntarse: ¿por qué se perdió en gran parte Dios en esta discusión, de la búsqueda de una "vida buena"?, ¿nos habremos olvidado en la Iglesia de argumentar la convicción de Pascal frente al hombre y la sociedad actuales?: "no solo no conocemos a Dios más que por Jesucristo, sino que tampoco nos conocemos a nosotros mismos más que por Jesucristo. Nosotros no conocemos ni la vida ni la muerte más que por Jesucristo. Fuera de Jesucristo no sabemos ni qué es nuestra vida, ni qué es nuestra muerte, ni qué es Dios, ni qué somos nosotros mismos” (159). ¿No estará el ateísmo contemporáneo y sus consecuencias íntima-

(156) Ser académico, una vocación. Enfoque teológico, en: Publicación del Tercer Congreso Nacional Jubilar de la Academia (Universidad Católica del Norte), Antofagasta 2004, 51-52.

(157) Cf. las interesantes reflexiones de nuestro colega J. Silva, La misión de la Iglesia: la vida en Cristo, en: S. Yáñez-D. García (eds.), El porvenir de los católicos latinoamericanos, Santiago 2006, 47-60. En la misma publicación, fruto de las reflexiones del Centro Manuel Larraín, es interesante al respecto el artículo de P. Salvat, El desafío de la inclusión en la sociedad y en la Iglesia (95-103).

(158) En un escrito programático, P. Hünermann ha propuesto la tesis que el hombre se mueve hoy en día en toda clase de limitaciones, en una inabarcable relación de sentidos que remite a su vez a una serie de ensayos de significado, que son conscientes de la diversidad de formas culturales actuales. En este marco, el hombre moderno exige un significado último para la vida que le permita una relación llena de significado con los otros hombres y el mundo. Aquí, el rol específico de la teología consiste, para este teólogo, en conexión con las otras ciencias de la cultura, en representar la aspiración de Dios, que a través de la "mediación" de Jesucristo, implica para los hombres una orientación última para desarrollar una vida plena en el mundo y la historia (cf. Theologie als Kulturwissenschaft, en: K. Gabriel et al [ed.], Zukunftsfähigkeit der Theologie, Paderborn 1999, 45-52). 
mente unido a la anuencia de la cristología (v. gr. de la persona de Cristo) en la teología? (160); y en relación con esto último, ¿habremos tomado en serio el diagnóstico de la era conciliar de Congar, que "los hombres desean una humanidad sin Dios porque nosotros les hemos presentado una teología que no implicaba de forma directa una antropología"? (161) Y es aquí precisamente donde se revela el carácter esencial de la diakonia de la que venimos hablando: ¿bajo qué condiciones del pensar es posible hacerse cargo de la búsqueda de una "vida buena" en un horizonte metafísico, a la luz de la revelación de la "verdad" de aquella pesquisa en la vida de un hombre como Jesucristo, que se refiere a sí mismo como "la verdad" del hombre nuevo pues habla con una autoridad dada por su condición de $\mu$ ovo $\gamma \varepsilon v \eta / \varphi$ de su Padre? Y ¿qué consecuencias tiene que el Padre creador haya tenido en Jesucristo, en el sentido de Ireneo, el modelo original con el que moldeó al hombre y la creación? Estas preguntas a su vez suscitan otras: si la verdad implica hacerse cargo del problema del "todo", ¿qué sucede cuando este se entiende en teología como el "reino de Dios"?, ¿no implicará esta última interrogante aceptar el desafío que es posible en todas las dimensiones de la realidad, de la existencia humana, pensar a Cristo como la clave que permite afirmar una plenitud anticipada? Y si la verdad es también emeth, que exige del hombre una actitud receptiva -en un movimiento dialéctico más allá de la disyuntiva pasividad-actividad-, ¿no será el testimonio eclesial -de fidelidad a la verdad que lo haga "digno" (Glaubhaft como dice Balthasar) de confianza- de realizar una existencia en donde todas las dimensiones que la Iglesia representa de la vida humana trasparentan del reino de Dios, una condición de posibilidad básica para hablar en serio de verdad, una verdad que por cierto ella sirve y no posee? (162). Y por último, si en la actualidad importantes filósofos -en una tradición que se remonta por ejemplo a Schelling, quien reflexiona cristianamente sobre la verdad del ser como amor- han relacionado verdad con amor (por ejemplo García-Baró), ¿no será el "testimonio" como una existencia agápica, proexistente (163), la conclusión básica sobre la verdad que realiza la teología, como discurso que permite descubrir en una historia contingente una exigencia de verdad, de adhesión, pues en esa historia el amor personal de Dios acoge a todos los hombres y les revela su verdadero rostro?

Así, el desocultamiento que provoca una "praxis", la del Reino de Dios, la de Jesús mismo, es la fuente primera para unir el evangelio y las preguntas concretas del hombre actual en vistas a una "vida lograda" (164). Y porque ese desocultamiento acontece en cada hombre y está llamado a realizarse de forma universal puesto

(159) Pensamientos, Br. 548.

(160) Esta es una hipótesis central del interesante libro de M. Buckley, At the Origins of Modern Atheism, New Haven 1987, 33.55.64-67.350-369 (en el cual también incluye el olvido de la pneumatología).

(161) Jésus-Christ, Paris 1965, 40.

(162) Cf. las ricas reflexiones al respecto de C. Geffré, El cristianismo ante el riesgo, 86ss, y el iluminador estudio de Kasper en donde relaciona el testimonio eclesial con el deber de presentar al amor como la verdad, La Iglesia, lugar de verdad, en: Teología e Iglesia, 351-375.

(163) Cf. K.-H. Menke, Die Einzigkeit Jesu Christi, 170ss.

(164) Cf. W. Kasper, Einführung, 11. Son iluminadoras aquí las palabras de M. Schibilsky: "La pérdida de significado de la teología en el siglo XX es... en primer lugar la pérdida de competencia de las teorías teológicas para interpretar la cotidianeidad, en vistas a otorgar a los miembros de la 
que implica el reconocimiento de la presencia de lo divino allí donde el hombre existe, con independencia de que la existencia de una Iglesia supone la profesión explícita de una misma fe. Y dicho desocultamiento está llamado a realizarse también una y otra vez, y de forma indefinida. La verdad acontece siempre la misma y al mismo tiempo también de forma novedosa ("signos de los tiempos").

Para concluir: con lo dicho se ha pretendido únicamente exponer la tesis de que la aceptación del cristianismo supone un concepto de verdad como desocultamiento, de tal modo que la realidad se constituye en ese desocultamiento; que como consecuencia de tal desocultamiento que llega a su plenitud en el hombre, este es completamente diferente de lo que son sus funciones concretas dentro de la sociedad, sin que quepa considerarlo como un simple dato o como una realidad entre otras; es su realidad, limitada y finita, y sin embargo absoluta en ese orden. Y por último, la verdad como desocultamiento no está ya prefijada sino que acontece y se constituye en cada caso, en un proceso incierto, no previsible y, al mismo tiempo, dotado de sentido y pleno de esperanza, porque una vez -que es todas las veces- en un hombre -que es todos los hombres- Dios asumió misteriosamente nuestra naturaleza.

Nuestras reflexiones han intentado, así, hacerse cargo de un concepto de verdad en relación a la interrogante que nos convoca en este Seminario, que lleva consigo un cambio del rol sistemático de la pregunta por la verdad (165). Este rol, pensamos, es otro que el de la simple lógica positivista o de la doctrina de la adaequatio (166), con lo que lo significativo no es ya la respuesta (167) sino la misma pregunta (performativa) por la verdad.

sociedad contemporánea una guía en relación a la vida" (citado en S. Orth, Was ist gute Theologie, Herder Korrespondenz 59 [2005], 259). Dentro de las reflexiones que ha suscitado el Centro Manuel Larraín, destaco por su importancia para nosotros, el aporte del sociólogo Jorge Larraín, quien propone profundizar sobre un nuevo marco para la evangelización, que tome muy en cuenta las preguntas del hombre contemporáneo. Y esto último por la siguiente razón: si una "verdad" se queda como algo meramente externo y el hombre no puede "presentirla" como algo propio, como un suceso que tiene que ver con $s u$ apertura al desocultamiento de lo verdadero en el contexto de $s u$ vida fáctica, esta verdad podría aparecer como algo valioso, pero a lo cual sin embargo solo se "somete" el entendimiento y la voluntad por razones externas (obediencia, tradición, etc.), pero nunca por el movimiento propio interno del espíritu que busca la verdad (cf. Globalización y evangelización, en: S. Yáñez y D. García [eds.], El porvenir, 165-177). En este sentido consideramos clave la siguiente afirmación de Geffré en relación al vínculo entre verdad y Cristo en clave de testimonio: "En otras palabras, el diálogo entre dos personas conduce al diálogo consigo mismo y entonces se atestigua y se celebra en ese diálogo la verdad. Quizá el objetivo del testimonio, cuando es testimonio ante Dios y testimonio desinteresado, no es intentar hacer del otro lo que no era hasta entonces..., sino tratar de hacerle llegar a sí mismo: ser revelador de su propia verdad o revelador de una posibilidad de existencia hasta ahora oculta" (El cristianismo ante el riesgo, 227).

(165) Que en el caso de la cristología (y la teología) es la pregunta por la verdad del Reino de Dios.

(166) En este aspecto resultan muy iluminadoras las reflexiones de C. Geffré, El cristianismo ante el riesgo, $78 \mathrm{ss}$.

(167) "Dios, si es verdaderamente Dios, no puede entrar en el reino de la verdad si no es como un significante que abre el campo de la manifestación, no como lo que encierra el poder de significación en una respuesta última. Si tiene sentido, debe tenerlo en cuanto que tiene una superpotencia de dar sentido" (A. Vergote, Interprétation du langage religieux, Paris 1974, 52). 


\title{
RESUMEN
}

A partir del desafío misional que se le plantea a la teología actual, de realizar afirmaciones universales salvíficas a partir de un hecho revelador concreto, la figura de Jesucristo, la cristología emerge como un campo paradigmático para reflexionar a fondo el reto recién señalado. En Cristo, "universal concreto", se revela la verdad de la humanidad, el cosmos y la historia, como señala el Concilio Vaticano II, en donde la idea de verdad debe ser pensada más allá de las formas clásicas de la "adecuación" y de los estrechos márgenes de la lógica y ciencia moderna: esta idea debe ser interpretada ante todo, apoyándose en Heidegger, como acontecimiento, donde se revela el sentido de la creación. Para poder expresar estas convicciones, la teología puede servirse del ejemplo de cómo algunos representantes fundamentales de la filosofía moderna (Kant, Hegel por ejemplo), han pensado la aparición de lo histórico en relación a la pregunta por el destino y sentido de lo universal.

Palabras clave: Verdad, cristología, acontecimiento, particular, universal.

\begin{abstract}
From the starting point of the missionary challenge that modern theology poses, by making universally salvific statements from a concrete act of revelation the figure of Jesus Christ $^{\sim}$ Christology emerges as a paradigmatic field for in-depth reflection upon this aforementioned provocative assertion. In Christ, "concrete universal", the truth about humanity, the cosmos and history is revealed, as Vatican Council II indicates. This is where the idea of truth must be considered beyond the classic forms of "adjustment" and of the narrow margins of logic and modern science. This idea must be interpreted, before anything else, based on Heidegger, as event, where the meaning of Creation is revealed. In order to express these convictions, theology can be served by the examples of how some fundamental representatives of modern philosophy (Kant and Hegel, for example) have considered the appearance of the historical in relation to the question of destiny and meaning of the universal.
\end{abstract}

Key words: Truth, Christology, event, particular, universal. 
